Anticle IX.-A Preliminary Report on the Animals of the Mississippi Bottoms near Quincy, Illinois, in August, 1888. Part I. By H. Garmax.

\title{
THE LOCALITY.
}

The peculiar features of the waters examined while with the Fish Commission at Quincy, in August, 1889, are reflected in the character of the collections taken from them. The locality is not one which would be selected by the naturalist as likely to yield a great variety of species. The waters are too much alike and are too much at the mercy of the Mississippi River for that. It is a localitr, howerer, that is eminently characteristic of the Mississippi Valley, and one that is calculated to yield a fauna equally characteristic of certain influences which the great stream exerts upon its denizens.

The flood-ground of the Mississippi River at Quincy will average six miles in width from bluff to bluff and extends very nearly north and south. The river reaches the bluff on the Missouri side at the village of LaGrange, nine miles northwest of Quincy. From LaGrange it flows southeast in a direct course to the bluffs upon which Quincy stands. As this part of the river is but little more than a mile in width, it will be seen that extensive bottom-lands must lie on both sides of it between LaGrange and Quincy. On the Missouri side these bottoms form an extended and continuous body of land,- - all wooded except the upper part, which is known as Lone Tree Prairie.

It is to the forest bottom-lands on the Illinois side northwest of Quincy that we wish to call especial attention, since it was upon them that most of our work with the Fish Commission was done. Unlike the Lone Tree Prairie region, they are cut up by channels into numerous separate bodies of land, upon sonie of which the water rises in spring, and leaves, as it subsi les, numbers of lakes and ponds, some permanent, others transient. Opposite LaGrange some of these tracts are per- 
manently detached from the main-land and form a group of large forest-covered islands. Including the chamnels between these islands, the river here has the unusual width of nearly three miles. Between the islands and the bluff is a fertile bottom-land, now protected from inundation by the Indian Grave levee. From this, the widest part, the Illinois bottoms become gradually narrower towards Quincy, just as those of the Missouri side do towards LaGrange, and terminate in a point known locally as the "tow-head." All of the lower part is without levee protection and is separated from the neighboring bluff by Quincy Bay, a narrow inlet which opens to the river at the tow-head, and extends thence northward close along the bluff for about three miles.

\section{THE RIVER.}

As has been said, the river averages abont one mile in width. While the general course between LaGrange and Quincy is nearly direct, the low-water channel makes several bends. It runs along the face of the bluff at LaGrange, then turns southeast, at length reaching the Illinois side close to the south end of the LaGrange group of islands, and strikes the Illinois bottom-land about three miles north of Quiney, cutting down the banks vertically, momdermining and carrying away the trees and threatening even to cut across to the bay. It then turns toward the Missouri side again and reaches it two miles below. Thence it is deflected towards Illinois, and passing close along the sonth end of the tow-head, follows the bluff along the lower part of Quincy. It flows at the rate of three miles an hour. These bends in the low-water channel are not specially noticeable to the landsman at high water, since the river then fills its whole bed. In the latter part of summer, during most seasons, the water subsides to such an extent that a good deal of the extensive sand-bar which has accumulated in each bend becomes exposed, and the river is confined to its low water channel. One such bar occurs in the bend west of the lower end of the Illinois bottom-land, and another on the Missouri side opposite the point at which the current strikes the same bottom-land above. In the river proper no serious work was attempted, because of the protracted high water due 
to heavy falls of rain in early summer. This was going down when we reached Quincy in the latter part of July, and the sand-bars in the bends began to appear soon after; but in August heavy rains in the northwest caused a rise which again covered them. This condition of the river liad a decided influence on the abundance and variety of animals, both in the lakes and sloughs and in the river itself. It will be referred to again.

\section{BEAR CREEK.}

This stream winds down through all the northern part of the Illinois bottom-land, and after giving off several branches to the Mississippi River on the west, reaches the upper part of Quincy Bay, into which it formerly opened. At present the building of the Indian Grave levee across it, a short distance within this month, has closed the outlet, and the only water discharged into the bay passes through a sluicegate. The lower part of the creek is now, therefore, little more than a slough. This was well filled with water when examined, and a small stream issued from a break which, during a recent inundation, it had made in the levee. The banks are steep, as a rule, as would be expected from the alluvial character of the soil through which the channel is cut. The shores are commonly wooded, and originally, doubtless, the whole of the neighboring region was covered with forest. The bottom is extremely muddy, and from the abundance of suags and brush lodged in its channel and its stagnant water, it is not an inviting collecting ground for the naturalist.

\section{BALLARD SLOUGH.}

This is a channel which has been cut obliquely across from the Mississippi River to Bear Creek, reaching the latter about a mile and a half northwest of the point at which the levee crosses the creek. Its river end, covered by the levee, is a half mile further north, and the length of the slough is probably not far from one and a half miles. It was, when visited, quite shallı, and extremely muddy, and varied greatly in width at different portions, sometimes expanding into pools of consid- 
erable extent, and again contracting to fifteen or twenty feet in width. It was not continuous at this time, and probably during most seasons dries up in great part before the close of summer.

\section{HARKNESS SLOUGH.}

Harkness Slough is a channel which extends almost exactly parallel with Ballard Slough, and lies a quarter of a mile further south. It is very narrow, - not fifty feet across in much of the lower part of its course; has steep banks; forms some rather deep pools ; and is, like Ballard Slough, extremely muddy. A dense growth of trees lines its banks. It was continuous as far as followed towards the Mississippi River (although greatly reduced at some points), and, judging from the current, was doubtless yet connected with the river. Still there can be no doubt that it commonly dries up largely in summer.

GOOSE LAKE.

An eighth of a mile south of the outlet of Harkness Slough into Bear Creek, is a wide opening on the east into Goose Lake,an open sheet of water, from the shores of which much of the forest has been removed. It becomes shallower and its bottom more sandy towards its south end, from which a channel extends which formerly put it into communication with the bay, three quarters of a mile below.

\section{LIBBY LAKE.}

This name was given me by one of the fishermen for a long, narrow pool on the west side of Bear Creek about midway between the outlet of Goose Lake and the Bear Creek sluice-gate. It is not named on any map at hand. It was in some respects very different from any other water in which collections were made. The water was quite deep, and, for the situation, unusually clear and cool, and gave promise of a growth of aquatic and sub-aquatic vegetation at the edges later in the season. It is scantily edged with willow and button bush and a few other trees and shrubs. 


\section{QUINCY BAY.}

The four bodies of water just described are within the levee. Quincy Bay extends from the levee where this reaches the Illinois bluff (about three miles and a half north of Quincy) directly southward along the foot of the bluff to the tow-head opposite the center of the city, at which point it opens to the river. It varies little in width and will average perhaps a third of a mile. It is little more than an inlet of the Mississippi containing back-water during the latter part of the year, the water in much of it becoming then very shallow and the current almost disappearing. During the month spent at Quincy this year, the water did not reach its usual low stage, and the current due to waters received from Bear Creek, and the sloughs, creeks, and springs, was sufficient to keep the bay quite clear of the algæ which would otherwise have appeared upon it. Its bottom is commonly muddy and no promise of other aquatic vegetation could be seen in it. It is edged with woods quite continuously on the west, and on the east also there is some growth of forest where the strip of level soil between the bay and the bluff gives room for it.

\section{WILLOW SLOUGH.}

This narrow channel extends obliquely across from the river to the bay outside of and parallel with the levee. It enters the bay about one and two thirds miles above the south end of the tow-head, and leaves the river a little over four miles north of the same point. Its length is about two and two thirds miles. At high water a current from the river sweeps through and reaches the bay; but at the time it was seen but little water ran ont; and in the lower part of its course it consisted of stretches of water connected by narrow rivulets. Some of the pools were of considerable depth. The bottom is commonly muddy, but occasional beds of sand occur. There was no vegetation.

WOOD SLOUGH.

Wood Slough is also a narrow channel extending obliquely across the lower part of the Illinois bottom-land from river 
to bay. It formerly entered the bay opposite the north end of Quincy, but the building of an embankment for a railroad bridge cut it off from this outlet so that it now turns' west at its lower end and, running along the embankment, empties into the river again. Throughout its course it is very nearly parallel with the west shore of the bottom-land, in some cases being only a few rods away fron the river. The river enters it four niles northwest of Quincy, and a mile and a half below this it breaks through the bank to the river again, so that at low water its lower part may not be continuous with the rest. It is perhaps three and a half miles long, - a narrow, muddy ditch of shallow water, completely devoid of vegetation, and containing such animals only as are so unfortunate as to be entrapped in it by the subsiding spring floods.

\section{CLAUS LAKE.}

This lake is a small temporary pool in the bottom-land about one fourth mile east of the north division of Wood Slough. It is very shallow, - at no place up to the mens' waists; has the usual muddy bottom; and lacks vegetation.

\section{DEAD MAN'S SLOUGH.}

Dead Man's Slough is a name applied by the fishing crew to a shallow, muddy pool in the woods about a quarter of a mile from the river above the north end of Wood Slough.

\section{MOSS LAKE.}

Moss Lake, on the southern part of Long Island, the largest of the LaGrange group, is very similar to the last two in general character, being an isolated pond in the woods. It is, however, much deeper than they, and its water is cooler and clearer. It is surrounded by a growth of hickory, elm, sycamore, and grape. Its length is less than a fourth of a mile, and its width from 150 to 200 feet. No aquatic vegetation was growing in it when it was seined in August.

\section{LILY LAKE.}

Lily Lake is one of a group of three lakes which lie between the lower end of Wood Slough and Quincy Bay. They 
have a common outlet during the fore part of the summer through Wood Slough. Lily Lake is the smallest of the three, and lies only a few rods from the west shore of the bay. It is an oval pond of shallow water full of the pads of water chinquepin, and is the only water from which I collected that contained a growth of vegetation. It is pretty well protected on the north and west by forest, which probably prevents to some extent the ravages of overflows.

\section{LONG LAKE.}

Long Lake, the second of the group, lies a short distance northwest of the preceding. It is nearly three quarters of a mile long, and is a narrow body of rather deep water surrounded by forest.

\section{BROAD LAKE.}

West of the lower half of Long Lake is the third lake of the group. It is broad and shallow, and when visited consisted of a series of detached pools with sloping bottoms of mud so deep as to make it extremely difficult to drag a seine.

\section{CEDAR CREEK.}

This is a small rapidly flowing creek which comes from the east and, cutting throngh the bluff, enters the bay half. a mile above the city limits. At its mouth it has deposited a large bed of alluvium through which one sinks to his knees in wading. A short distance from the bay it becomes rocky, and between the bluffs and in the upper part of its course flows over almost solid limestone. When visited, it was noderately low, and in places were shallow pools connected with each other by narrow reaches along which the water rushed with considerable speed. The water is quite clear notwithstanding the sewage which it receives; yet the influence of the latter is seen in the comparative scarcity of arquatic life for some distance back of the bluff.

\section{OTHER WATERS.}

The only situations other than those described above, in which collections were made, were a small creek without name just above Quincy, which is similar to Cedar Creek in every re- 
pect except its smaller size, and a muddy pond near the bluff at the southern' limit of Quincy.

It was from the lakes and sloughs thus briefly described that the material was obtained upon which this paper is based. Omitting Cedar Creek, the bay, and the river, they have much in common. All were, or are now, subject to overflow by the Mississippi. Since the Indian Grave levee was built, the waters within it,-Bear Creek, Harkness and Ballard Sloughs, and Libby Lake,-have not commonly been subject to inundation, - a fact which explains certain special features of the collection taken from them. The condition of the pools with reference to the river was not a usual one. A late rise in the river had flooded them after the spring freshets had subsided, and kept open the communication with the river much longer than would otherwise have been, thus helping the large fishes to escape from them after spawning, and doubtless carrying away hosts of the smaller organisms which had appeared in the pools. All have very muddy bottoms. In most, this mud was nearly knee deep, and made seining very difficult and disagreeable. In some places deposits of mud were of such recent origin and were so loose that it was unsafe to venture into them. Aquatic vegetation was almost wholly lacking. A scant growth of filamentous alga was occasionally seen, but in nothing like the quantities in which it occurs in ordinary stagnant or quiet water. In Lily Lake alone there was a rank growth of aquatic vegetation. Here a permanent growth of water lilies (Nelumbium luterm) had become established, and to the under sides of the lily pads was attached a scant growth of filamentous algat. This absence of vegetation is directly traceable to the overflows, since these disturb the bottoms of the pools, displacing the silt in some places, depositing fresh material in others, and dislodging and carrying away the plants which become established during the intervals between floods. The water was not rery deep at this time, but of course varied with the river. It could be waded in most places by the men. It was deepest in the larger pools, such as Long and Broad Lakes, and here the temperature was tolerably constant. In the sloughs, where the water was shallow, it often became very warm, and during a 
few days of unusually high temperature became at the edge of these so hot as to be scarcely bearable.

\section{ANIMAL LIFE.-MAMMALS AND BIRDS.}

With this sketch of the surroundings we pass to the animals themselves. Of course manmals were not to be looked for on land so recently covered with water, and no trace of the presence of muskrats, even, was noticed. The raccoon, however, is said to remain on the flooded ground at all times, resorting to the trees, and probably often fasting, when surrounded by water. These animals were common about the sloughs, as was shown by the prints of feet, and doubtless depend to some extent on the fishes and other animals there crowded together. Fishes thrown upon the shore were generally devoured by them before the next morning. In the latter part of August they were plainly depending largely on wild grapes for food.

Birds were at no time abundant. A few kingfishers, a solitary green heron, or a couple of spotted sandpipers (Tringoides mucularius), were about all that were commonly seen during a day's work. As the season advanced these became a little more abundant from accessions of migrating birds to their numbers. At one time a flock of about forty white pelicans appeared for the greater part of a day on the Missouri sand-bar opposite Wood Slough, but were driven away by gunners and did not again appear. An occasional troop of cormorants was seen, a single blue heron, a dab chick (Podilymbus. podiceps), and two half-grown ducks, one of which was brought in by the seine. When the wild grapes ripened, the bottomland was invaded by a good many of the smaller birds which were not often seen there before. Among these, robins, redheaded woodpeckers, and blue jays were conspicuous, though I cannot say that the two latter were attracted by the grapes. One other bird deserres mention as, from the numbers in which it occurs, it must have an important influence upon the insect life of the waters. Certain parts of the bluff presented extensive vertical surfaces of exposed elay, and bank swallows, in great numbers, had excavated burrows in this for nests. In places these exposed surfaces were honey-combed with the 
burrows. During quiet afternoons and evenings the swallows spent a good deal of time skimming the surface of the water of the neighborhood. Among them was noted occasionally, the white-billed swallow (Tuchycinctu bicolor); but most seemed to be the bank"swallow (Clivicola riparia). There can be no doubt that the destruction of winged insects from the water by the hundreds of swallows annually reared in these banks is very great.

\section{REPTILES.}

With one exception, serpents, even of the aquatic kinds, were not seen. I presume they are not able to maintain themselves on the bottom-land during inundations. A single Regina lcberis was seen for several days lurking about fish boxes at the headquarters of the Fish Commission. The absence of vegetation may also have had something to do with the absence of serpents, since they prefer places in which they are not so completely exposed to observation. The locality was certainly calculated to furnish an abundance of food to the fish-eating species.

Turtles were present in great numbers. They were especially common in the more retired pools when these were first visited. Subsequent visits showed them in diminished numbers, either from their having migrated, or having learned to avoid the seine by burrowing in the mud. The egg-laying season was apparently past, so that no opportunity offered for studying the breeding habits of the species. I am informed that the eggs are sometimes gathered from sandy shores by hundreds, and used as food.

The following brief list includes most of the species of Chelonia which occur in Illinois. Doubtless some of the other Illinois species will also be found here when the locality is niore thoroughly explored.

\section{Painted turtue (Chrysemys belli, Gray).}

This turtle was rather common in the sloughs, but was not seen elsewhere. Adults are not easily distinguished from the related $C$. marginata; but I believe none of the latter occurred in the sloughs. 
Pseudemys elegans, Wied.

Frequent in sloughs.

Pseudemys troostii, Holbrook.

Rare. Three examples from Moss lake, on Long Island, in the river. A strong, irritable species.

Mun Turtee (Malacoclemmys lesueuri, Gray).

Equally common with the next species and much like it in habit. The two are not discriminated by river men, and are known to them as mud turtles. Observed in most of the sloughs and in the river and bay.

Mud Turtue (Malacoclemmys geographicus, Lesueur).

This and the preceding species probably constitute more than half of the turtles which one sees on the partly submerged trunks of trees and on sunny banks along the river and sloughs. Scores may be seen on bright days sunning themselves on the edges of the $\log$ rafts in the upper part of the bay. They are not used as food, though it is sometimes claimed that the flesh is palatable.

Alligator Sxapper (Macrochelys lacertina, Schw.).

This species is said by fisherman and sportsmen to occur here occasionally.

Sxap'ring Turtue (Chelydra serpentina, Limn.).

Occasional in sloughs and lakes. Those taken were large and very fat. It is prized as food.

Soft-Sheld Turtle (Aspidonectes spinifer, Lesueur).

Abundant in river and not uncommon in the sloughs. Fishermen sell readily those caught in their seines.

Sort-Shla Turtle (Amyda mutica, Lesueur).

Common in the river, but less abundant in sloughs than the preceding. lieaches a length of 8 to 10 inches. It is used as food.

\section{AMPHIBIANS.}

A mphibians evidently cannot maintain themselves on these bottom-lands. They were very rare; and probably the few seen had made their way in from the higher land within the 
levee. A few half-grown leopard frogs (Rana virescens, Kalm) were taken in the woods under logs, and at the edges of slonghs. One full grown example was taken at the edge of Claus Lake August 10. A single R. catesbiuna, Shaw, was heard within the levee in Bear Creek. The cricket frog (Acris gryllus, LeConte) was frequently seen at the edges of the water, but was by no means common. Two young toads about half an inch long were taken at the edge of Lily Lake August 7, and another example 1.25 inch long was taken August 15 at the edge of Willow Slough. The former had probably grown from spawn deposited in the water after the late floods. They were found on the side of the bottom next the bluff. It may be that a few adults succeed in avoiding the current on this side and remain here; but they are certainly rare. Not a single tadpole was noticed in any of the bottom-land sloughs and lakes; but a few small tadpoles of toads were noted in shallow pools of Cedar Creek. All these amphibians were feeding on terrestrial insects,-chiefly beetles belonging to the families Carabidæ, Staphylinidx, and Heteroceridx, together with a small $\mathrm{fly}$, and leaf-hoppers of the family Jassida. One cricket frog had eaten a single aquatic larva (the Acilius described below). There was little difference in the food of the different species from any one locality. Along Cedar Creek a small black fly, which was common on moist sand, was eaten largely.

\section{FISHES.}

The fishes taken from the sloughs and lakes of the bottom-land at Quincy, may be placed in three groups: creek fishes, pond or slough fishes, and river fishes. To the creek fishes belong most of the minnows, the sand darters, and the common sucker,-altogether about half as many species as there are in each of the two remaining groups. The individuals belonging here were probably less than one per cent. of those taken from the pools. This scarcity was due in some measure to the abundance of predaceous fishes in these waters; but the species of this group taken were mostly such as are ordinarily found common in small creeks, and were probably only stragglers from the great body of individuals which live in such streams. Several of the minnows, however, deserve to be 
placed among river fishes as far as fitness for life in the river is concerned. Such species as Hybopsis amblops, Notropis atherinoides, $N$. jejunus, and Hybogmathus nuchalis, though occurring in small streams, generally prove abundant in our rivers, and are certainly perfectly at home there.

I have considered as pond and slough fishes, such as the bull ponts, the top minnows, the two pickerels, the two croppies, the several species of sunfishes, the large-mouthed black bass, and the ringed pereh. The members of this group were commoner in the sloughs than were those of the preceding group, but were not as abundant in species or individuals as the next. In the lakes and sloughs outside the levee, probably these pond fishes did not constitute more than one fifth of the individuals taken; but inside the levee they composed one half of those taken in all situations. Some of them were evidently breeding in these protected waters, and I do not think any member of the group was doing so in the sloughs of the lower bottom-land.

The third and largest group includes river fishes, such as gars, dogfish, channel cat, morgan cat, shovel fish, buffalo, carp, several minnows, the Ohio shad, pike, perch, striped bass, white bass, red-spotted sunfish, and the white perch (Aplodinotus.) These fishes must have constituted in the neighborhood of four fifths of the individuals in the sloughs and lakes outside the levee. A number of them, notably the hickory shad and the red-mouthed buffalo, occurred there in prodigious numbers. As a rule, these species became gradually less and less common as one went north and away from the river, and accompanying this diminution in the numbers of river fishes was a gradual increase in the numbers of pond fishes. There was, in fact, an overlapping of the two groups in the bottom-land, the river fishes being most abundant in the slonghs near the river, and the pond fishes, within the levee and to the northward. Still, several river fishes were very common inside the levee. Evideutly not all of the river fishes taken in the sloughs breed there. Such species as the morgan catfish (Leptops), the shovel fish, the minnows, and the red-spotted sunfish (Lepomis humilis) had probably wandered here from the river during high water and had been confined when the water became low- 
er. Most of the remaining river fishes had, I think, been spawned on the flooded bottoms: The abundant young. of gars, buffalo, carp, hickory shad, pike perch, and white bass in the temporary pools are evidence of this.

FAMIJY SCLANIDi:

Siremsiread, White Perch, (Aplodinotus grumiens, Raf.)

The young of this fish, varying from 2.50 inches to 4.50 inches in length, were frequent in most of the sloughs and lakes. These are, in all probability, the young of the season. If smaller ones existed in the sloughs, they would certainly have been captured in the seine used by the Fish Commission (a quarter-inch mesh). This species was more abundant inside the levee than in the pools on the lower part of the bottomland, and was especially common in inlets along the lower part of Bear Creek and in Loose Lake. On a small sand bar in Bear Creek, at the month of Harkness Slough, more were taken than at any other one place. No specimens longer than 4.50 inches were taken from the slonghs and pools, so far as I know. In the bay and river, large ones were very common; and probably half of the fishes taken during Angust with hook-and-line from barges and river banks were of this species. It seems quite at home in the swiftest current of the river, and was caught with minnow bait from banks upon which the current strikes with a force which it would seem no animal could, withstand. The largest example seen would have weighed about one pound. The local name for the fish is perch; and it is considered one of the best of food fishes.

Localities: Ballard Slough, Harkness Slough, Bear Creek, Goose Lake, Quincy Bay, Claus Lake, Willow Slongh, Lily Lake, Broad Lake, Wood Slough, Mississippi River.

\section{Famity SerRanidi.}

Stripen Bass, Yellow Bass (Morone interrupta, Gill),

Young were frequent in certain of the sloughs and lakes, but were not seen elsewhere. In the northern part of Broad Lake and in small isolated pools above it, they were quite common. Examples preserved vary from 1.75 inch to 4.50 inches in length. 
Localities: Ballard Slough, Harkness Slough, Goose Lake, Dead Man's Slough, Claus Lake, Willow Slough, Lily Lake, Broad Lake.

White Bass, Rock Bass (Roccus chrysops, Raf.).

This fine species was more abundant than the striped bass, and ranged in a greater variety of situations. I saw it caught from the swiftest current of the river. Only young ranging from 2.50 to 5 inches in length were found in the sloughs. It was nowhere common except in the upper part of Broad Lake and in the pools which had recently been in communication with it.

Localities: Ballard Slongh, Bear Creek, Goose Lake, Dead Man's Slough, Moss Lake, Willow Slough, Long Lake, Broad Lake, Wood Slough.

\section{Family Percider. (Perch.)}

Sauger, Jack Samon (Stizostedion canadense, Smith).

Young frequent in lakes, varying from 3 to 5 inches in length. No adults seen.

Localities: Goose Lake, Claus 'Lake, Lily Lake, Long Lake, Broad Lake.

Watl-eyed Pike (Stizostedion vitreum, Mitch.).

Young frequent in most of the sloughs and lakes; sometimes abundant. Ranged from 2.50 inches to 6 inches in length. Frequently with large, conspicuous, dusky blotches.

Localities: Harkness Slough, Goose Lake, Willow Slough, Lily Lake, Long Lake, Broad Lake, Wood Slough.

Cummox Rinaed Percin (Perca flacescens, Mitch.).

Young ringed perch were occasionally seen in the bottomland lakes. Those captured ranged from 2.75 to 3 inches in length. In Libby Lake, within the levee, these fishes were abundant, - a fact which was noted with surprise, as they had not hitherto been found common in the State away from the northern part. Those taken from this lake differed from the northern lake form in being rounder; and also especially in color. When taken from the water they were almost nniformly olive green above, with white belly. As they died, faint 
blackish bars gradually appeared. Mr. Bartlett tells me that he has transplanted perch to this locality,-a fact which probably accounts for the abundance of the fish in Libby Lake.

Localities: Libby Lake, Dead Man's Slough, Long Lake, Broad Lake.

Sand Darter (Etheostoma jessiu, Jor. \& Brayt., var. "sprigene, Forbes).

Judging by the number of specimens of this little fish taken, it is not common here, although parts of Willow slough are well suited to it.

Four examples, Willow Slough; one large brightly colored example, Broad Lake; one example, Lily Lake.

Sand Darter (Etheostoma phoxocephulum, Nelson).

Occasional in Wood Slough. Excepting a single example from Willow Slough, it was not seen elsewhere.

Blackis-ded Darter (Etheostoma aspio, Cope \& Jor.).

One small example approaching E. phoxocephalım in colors, was taken in Wood Slough, July 30.

Log Perri (Etheostoma caprodes, Raf.).

This was the most abundant darter collected. It was quite common in Willow Slough, Long Lake, Broad Lake, and Wood Slough.

Johnn y DARTer (Etheostoma nigrum, Raf.).

An immature example from Willow Slough was the only one seen.

\section{Family Centrarchida. (Sunfishes).}

Large-Mouthen BLACK Bass (Micropterus sulmoides, Lac.).

The young of this bass were moderately common in all the sloughs and creeks. Examples of considerable size were occasionally taken, showing that this species does not necessarily leave the sloughs after spawning. One example brought in by the net must have weighed seven pounds or more. The smaller examples, which are of interest as in all probability the young of the season, ranged from 2 to 3 inches in length. Between these and the larger ones were various intermediate sizes representing probably three or four generations. 
Localities: Ballard Slough, Harkness Slough, Libby Lake, Moss Lake, Dead Man's Slough, Claus Lake, Willow Slough, wouth of Cedar Creek, Lily Lake, Long Lake, Broad Lake.

Syald-Mouthed Black Bass (Micropterus dolomieu, Lac.).

A single young specimen 2.12 inches long, was taken in Willow Slough August $\%$. The locality is somewhat unusual for this species. It is certainly not conmmon in the water collected from. Mr. Bartlett informs me that it was brought here some time ago by the State Fish Commission.

Common Sunfrsh (Lepomis pallidus, Mitch.).

Rare in the temporary pools, becoming common in the deeper water of Long and Broad Lakes; also quite common within the levee. The youngest examples taken ranged from 1 to 1.75 inch in length. Adults in breeding colors were caught in Long and Libby Lakes. Females contained ova as large as No. 12 shot. An old gentleman who has fished here for years tells me that in the days of the earlier settlers sunfishes, presumahly of this species, were sometimes taken that weighed as much as four pounds.

Localities: Ballard Slough, Harkness Slough, Libby Lake, Dead Man's Slough, Moss Lake, Willow Slough, Lily Lake, Long Lake, Broad Lake, Mississippi River.

Red-Spotted Sunfisir (Lepomis humilis, Gir.).

This handsome little fish was quite common in sloughs and lakes,- more abundant than we have found it elsewhere in the State. Very few young were seen, and these were nearly mature. It is quite hardy, as is shown by the water it frequents, and may prove a desirable aquarium fish. All the adults taken differed from the descriptions of Drs. Jordan and Gilbert in having the opercular flap with a wide $u$ hite margin instead of a red one. Imnature examples have the opercular flap, poorly developed and are marked in the sides with numerous suiall black dots, while the red of the adult is largely wanting.

Localities: Harkness Slough, Goose Lake, Moss Lake, Dead Man's Slough, Claus Lake, Willow Slough, Iong Lake, Broad Lake, Wood Slough, pond at southern limit of (quincy. 
Red-eye, Blue Spotted Sunfish (Lepomis cyanellus, Raf.).

Two examples about 3.50 long, taken in Goose Lake, Aug. 13 , were the only ones seen.

IVarmouth, Ren-eyed Bream (Chunobryttus gulosus, C. \& V.).

A few young, about 1.50 inch long, were taken in most of the pools. Frequent in Libby Lake and Harkness Slough.

Localities: Ballard Slough, Harkness Slough, Libby Lake, Dead Man's Slough, Claus Lake, Lily Lake, Long Lake, Wood Slough:

Pale Croppen (Pomoxys ammularis, Raf.).

The pale croppie was more abundant than we have found it elsewhere in the State away from Sonthern Illinois. This fact is one of a number which our fish famna vields, illustrating the influence of the Mississippi River in extending the range of southern species northward immediately along its course. Young, from 2.25 to 2.75 inches long, were common; and between these and the largest taken ( 8 inches long) were a number of intermediate sizes. The species became a little more abundant in the more northern pools.

Localities : Ballard Slough, Harkuess Slough, Goose Lake, Libby Lake, Moss Lake, Dead Man's Slough, Claus Lake, Willow Slough, Lily Lake, Long Lake, Broad Lake, pool at southern limit of Quincy.

Dark Croppie, Calico Bass (Pomoxys spruroides, Lac.).

A little more abundant than the preceding species in the sloughs and lakes. Especially common in the more northern pools, but very generally distributed. Most of those seen were young, from 1.50 inch to 2 inches long. No adults were seen from pools outside the levee.

Localities: Ballard Slough, Harkness Slough, Goose Lake, Libby Lake, Moss Lake, Claus Lake, Willow Slongh, Lily Lake, Isong Lake, Broad Lake, Wood Slough, pool at southern limit of Quincy.

\section{Family Esocide. (Pikes.)}

Pike, Pickerel (Esox lucius, Linn.).

This species was not seen in most of the bottom-land sloughs. Probably more work in the pools and lakes within 
the levee farther north would have shown it common enough. It probably does not often leave its retreats among the vegetation of quiet water for the current of the river.

From Harkness Slough, example 12 inches long; Libby Lake, several examples 8 inches long ; Long Lake, one example ; pool south of Quiney, a half dozen small examples.

Little Pickerel (Esox vermiculutus, Les.).

Not common apparently. Seen only within the levee and in Lily Lake.

Harkness Slough, one example; Claus Lake, occasional examples five inches long; Lily Lake, four small examples.

FAMiliy Atherinide.

Labidesthes sicculus, Cope.

Probably more common in the sloughs than it seemed to be, as its slenderness permits it to pass throngh most seines when they are not encumbered with vegetation. The pools are exactly suited to it. Lake.

One small example, Long Lake; four examples, Broad

\section{Fanily Cyprinonontide. (Top Minnows.)}

Black-sided Top Minnow (Zyggonectes notatus, Raf.).

Frequent and generally distributed, but only a few taken at any one tinfe. Schools of about a half dozen individuals were frequently seen in the bay.

Localities: Harkness Slough, Qniney Bay, Willow Slough, Long Lake.

\section{Family Clupeidas. (Simad.)}

Hickory Sinad, Gizzard Shad (Iorosoma cepedianm, Les.).

The bottom-land sloughs and lakes are pre-eminently the spawning ground of this tish. Young of the year, 1.50 to 2 inches long and still wearing the black shoulder nark, oceur in countless numbers. Probably more than half of the individuals taken in the Fish Commission seines during the season are these young shad. The temporary pools on the lower part of the bottom-land were crowded with them. They were less abundant farther back, but were still very common in Libby 
Lake, inside the levee. The adults, on the other hand, were usually searce; but in the pool south of Quincy both young and adults were common,- - a fact explained by the situation-of the pool east of a railroad embankment and at a considerable distance from the river. The pool is consequently very early isolated, and the adults which make their way in to spawn are prevented from escaping. Predaceous fishes confined in the slonghs depend very largely on this shad for sustenance.

Iocalities: Harkness Slough, Libby Lake, Moss Iake, Dead Man's Slough, Claus Lake, Quincy Bay, Long Lake, Broad Lake, Wood Slough, pool south of Quincy.

Onio Shad (Chupea chrysochloris, Raf.).

Probably not common. The only specimens seen were a half dozen young, 2.62 inches long, from Moss Lake, Long Island, Aug. 14.

\section{Fanili Cyprinidas. (Minnows.)}

Golden Shiner, Brean (Notemigonus chrysoleucus, Miteh.).

Frequent. Abundant in Libby Lake, where examples 5 inches long were seeu.

Localities: Harkness Slough, Libby Lake, Dead Man's Slough, Claus Lake, Long Lake, Wood Slough, pool south of Quincy.

Hybopsis amblops, Raf.

Common in Willow Slongh and of large size, some examples measuring 4.5 inches in extreme length. Elsewhere taken only in Broad Lake and Wood Slough, from each of which one or two examples were obtained.

Phencucobius teretulus, Cope.

A single example of this variable minnow was taken from Broad Lake, August 9.

Notropis atherinoides, Raf.

Not found common except in Moss Lake and in the'river. On the sand bars of the latter it is canght in numbers for bait. It was sometimes seen hurrying up stream near the shore against the force of the current.

Localities: Moss Lake, Mississippi River, Broad Lake, Long Lake. 
Notropis jejunus, Forbes.

One example, Long Lake; eight examples, Broad Lake.

SHINer (Notropis megalops, Raf.)

Rare. Two small examples from Willow Slough, the only ones secured.

Spawy Eater (Notropis hudsonius, Clinton).

Not common. One example each from Goose Lake and Long Lake.

Notropis cayuga, Meek.

The above name was assigned some time ago by Prof. Gilbert to numerous examples of a small minnow in the Illinois State Laboratory collection. Mr. Meek's description has not been seen, but a comparison of a single example of a fish obtained in Long Lake, with the specimens examined by Prof. Gilbert, shows this to be the sane thing. The species bears a superficial resemblance to Notropis heterodom, but has a short, weak mandible, without pigment, and a complete lateral line.

Cliola vigilax, Baird and Girard.

Frequent in several of the pools.

Localities: Willow Slough, Long Lake, Wood Slough.

Budnt-nosfo Minnow (Pimephales notatus, Raf.).

Less common than the preceding.

Long Lake, Wood Slongh.

Silvery Minnow (Hybognathis muchalis, Ag.).

This species was common in the river, where with Notropis atherinoides, it was taken in numbers for bait. Throughout Cedar Creek, also, it was very abundant, and in the upper part of the stream was the only fish seen. In the sloughs and lakes it was not common.

Claus Lake, Willow Slough, Broad Lake, pool south of Quincy, Cedar Creek, Mississippi River.

German Carip (Cyprinus carpio, Limn.).

This hardy fish seems destined to become a permanent part of our fauna. Examples of good size were takell on a number of nccasions, showing it to be widely distributed among the pools and lakes of the bottom-lands. A single specimen of 
the fully-scaled form was taken from Dead Man's Slough August 18. The food of an example from Broad Lake consisted of vegetation and mollusks, the former constituting two thirds of the material in the alimentary canal, and consisting of dead leaves and of seeds. The seeds were, as far as could be determined in a hasty examination, chiefly tlose of trees and weeds. Elm seeds, ragweed seeds and the seeds of Polygonum were noted. The Mollusca were partly thin-shelled clams with an occasional Sphrerium, and partly snails, such as Physa and Lioplax. All the matter was apparently gathered from the bottom. No trace of crustacean or insect food could be detected.

Dead Man's Slough, Broad Lake, Quincy Bay, and pool south of Quincy.

\section{Family Catostomidz. (Suckers.)}

Red Horse (Moxostoma aureola, Lues.).

Rare. Seen only on two occasions.

Moss Lake, five examples 5.50 to 6 inches long; Wond Slongh.

Red Honse (Moxostoma macrolepidotum, Les., var. duquesnei).

Occasional young 4.50 to 12 inches long were taken.

Localities: Moss Lake, Willow Slough, Long Lake, Broad Lake, Wood Slough.

Common Sucker (Catostomus tercs, Mitch.).

Rare. Those taken were about six inches long.

Localities: Moss Lake, Wood Slough, slough south of Quincy.

Carp, River CARP (Ictiobus velifer, Raf.).

Generally distributed but not very common, and nearly all young. Examples from 3.50 to 7 inches long were taken. Frequent in the slongh at south edge of Quiney.

Localities: Harkness Slough, Bear Creek, Goose Luake, Moss Iakke, Willow Slough, Long Lake, Broad Lake, IVood Slough, pool south of ( )uincy.

Quili-back Buffato (Ictiobus bubalus, Raf.).

Not observed in any of the bottom-land pools outside the levee, excepting Broad Lake. The young from 3 to 5 inches long were rather common inside the levee. The only large 
examples seen were taken from the river, where they seemed to be moderately common. The young are easily distinguished from the young of $I$. cyprinella by their small, inferior mouth, compressed body, and pale colors,-especially of the pectoral and ventral fins.

Localities: Harkness Slough, Bear Creek, Libby Lake, Dead Man's Slough, Claus Lake, Broad Lake.

Mongrel Buffalo (Ictiobus urus, Ag.).

In my field notes I have recorded the young of this fish as occurring in the slough at the south edge of Quincy. They were not seen elsewhere. Adults were common in the river, and were sometimes seen of large size. One was noted August 6 which weighed twenty and a half pounds.

Localities: Slough south of (Unincy, Mississippi River. Red-Mouth Buffalo (Ictiobus cypprinellu, C. \& V.).

Young 4 to 5.75 inches long were extremely common everywhere in sloughs and lakes. They differ from the young of $I$. bubalus in having a larger mouth, thicker body, and darker colors. The pectoral and ventral fins are blackish, whereas in the case of the quill-back buffalo they are pale. Most of the large buffalo taken from the river were of this species.

Localities: Harkness Slough, Bear Creek, Moss Lake, Dead Man's Slough, Claus Lake, Willow Slough, Long Lake, Broad Lake, Wood Slough, slough south of Quincy, Mississippi River.

\section{Family Siluride. (Catfishes.).}

Noturus gyrinus, Mitch.

Moderately common in sloughs and lakes,

Localities: Harkness Slough, Dead Man's Slough, Willow Lake, Lily Lake, Long Lake, Broad Lake, Wood Slough.

Morgan Cat, Yellow Cat ( Leptops olivaris, Raf.).

This eatfish was rare in sloughs and lakes. A single example 10 inches long from Willow Slough was the only one seen from water of this kind. It was abundant in the river, where specimens of ten pounds weight were frequently taken; and one was noted August 6 that wonld probably have weighed 18 pounds or more. I am informed that young dog-fish are used on trot lines as bait for this catfish. 
Bull-Head (Ameiurus melas, Raf.).

The most common of the small catfishes in the sloughs. They seem to be gregarious when young and small sehools were occasioually seen swimming slowly along in an aimless fashion in the bay. The examples taken measured from $1.2 \bar{j}$ to 2.75 inches in length. Adults were not seen.

Localities: Claus Lake, Wood Slough, Lily Lake, Long Lake, slough south of Quincy, Quincy Bay.

Bull Pout (Ameiurus nebulosus, Les.).

Not seen in most of the pools. Frequent and of large size in Dead Man's Slough.

Y

Not common. Those seen were adults.

Harkness Slough, one large example; Moss Lake, several large examples; slough south of Quincy, a few.

Willow Cat, Channel Cat, White Fulton (Ictalurus pumctatils, Raf.)

Young 5 to 7 inches long were frequent in some of the sloughs and were quite abundant in Bear Creek. No large examples were seen in the sloughs, but speciurens weighing from a half to three quarters of a pound were abundant in the river, as was seen by the numbers caught on trot lines. The young are called "fiddlers" by fishermen.

Localities: Bear Creek, Dead Man's Slough, Willow Slough, Long Lake, Broad Lake, Wood Slough.

\section{Family Amitda (Dog-Fisir.)}

Dog-Fisir (Amia calva, Limn.)

Young dog-fish were not often seen in the pools outside the levee, but inside they were everywhere common. They measured from six to eight inches in length. In Bear Creek they were especially abundant, sometimes sporting at the surface in great numbers. Adults were also taken inside the levee. They certainly spawn on flooded bottom-lands in early spring; and I can account for their almost total absence from the temporary pools only by supposing that the young follow the adults into the deeper waters as the bottom-lands become 
exposed. Young a few inches in length are caught by the hundred at times for trot line bait, their desirable quality for this purpose being an extreme hardiness when on the hook.

Localities: Ballard Slough, Harkness Slough, Bear Creek, Goose Lake, Dead Man's Slough, Moss Lake, Willow Slough, Long Lake, Broad Lake.

\section{Fanily Lepidosteid 玉. (GARs.)}

Short-xosed Gar (Lepidosteus platystomus, Raf.)

Young examples from 8 to 12 inches long were very common in some of the lakes and sloughs, and were seen frequently lurking about barges and fish boats in the bay. No large examples were seen. They are quite sportive at times, and keep up a constant splashing of the water as a skiff moves among them. Hundreds were seen at the south end of Long Lake. They were lying just beneath the surface, fanning the water with the fius sufficiently to keep the body stationary, and when approached would suddenly lash the tail out of water and disappear. The young of this gar averaged considerably larger than those of the other species and were more uniform in size. Eighteen examples taken at random from different situations average 9.94 inches in length from tip of snout to tip of caudal fin. With two exceptions all. those seen had lost the caudal filament, and also, to a great extent, the black blotches of the very young. Those which possessed the filament were tro of the three smallest examples taken, and measured respectively 8 and 8.50 inches in lengtb. The largest examples seen measured 12.50 inches. If these young are from the eggs spawned this season, and I believe they are, they indicate a more rapid growth, or an earlier spawning time for this species than for $L$. osseus.

Localities: Harkness Slough, Goose Lake, Dead Man's Slough, Claus Lake, Quincy Bay, mouth of Cedar Creek, Wood Slough.

LoNG-Nosed Gar (Lepidosteus osseus, Linn.)

The young were more abundant and more generally distributed than those of the preceding species. Thirty-eight examples give an average length of 8.10 inches. The smallest 
seen measured 6 inches in length, and the largest 12.25 inches. This last was the only one taken that had lost the caudal filament. The more uniform occurreace of this gar in bottomland pools of all sorts and its greater abundance there, in addition to the smaller average size of the young as compared with those of $L$. platystomus, suggest a later spawning time. If the short-nosed gar spawns earlier, its young have more time to escape from the temporary pools, and we should expect to find fewer of them present in August. The matter needs further attention, however, as a difference in the relative abundance of adults in the river at this point, or some unknown difference in spawning habit, may have to do with some of the differences we have noted.

Localities: Harkness Slough, Dead Man's Slough, Moss Lake, Claus Lake, Willow Slough, Lily Lake, Long Lake, Broad Lake, Wood Slough.

\section{Famidy Polyodontidæ. (Shovel-fish.)}

Shover-Fish (Polyodon spathula, Walbaum.)

This fish evidently does not spawn on the overflowed bottom-land. A single example about 14 inches long from Wood Slough was the only one taken. The adults are common in the Mississippi River, where they were occasionally seen leaping above the water.

\section{Family Petromyzontidas. (Lampreys.)}

Lamprex EeL (Petromyzon castaneus, Gir.)

A lamprey taken by the men from Wood Slough was probably of this species. It was not secured for examination.

\section{INVERTEBRATES.}

Small animals, such as insects, crustaceans, and mollusks, were not as abundant as they commonly prove to be in permanent bodies of water in other localities. The absence of vegetation and the abundance of their enemies, the fishes, doubtless both had to do with this. The condition of these pools, as we have seen, is not favorable to a growth of regetation, and the 
season was exceptionally unpropitious with respect to this: Those small creatures which did occur in the pools were thus deprived of the protection which a rank growth of vegetation affords, and could not be expected to maintain themselves where every square yard of bottom must have been searched each day by hungry fishes. Notwithstanding this condition of things, certain species occurred in considerable numbers. Such as have the curious habit of remaining motionless in the presence of enemies and such as burrow readily in mud, were very common in some of the pools. Consequently, when it is said that invertebrate animais were not common in these waters, it is meant that, as compared with permanent lakes elsewhere, there was not here a great diversity of forms represented each by an abundance of individuals.

\section{MOLLUSCA. (Shell Fish.)}

The Mollusca were represented in the locality by both Gasteropoda and Lamellibranchiata.

The snails were nearly all of small size, none of those seen having shells over 1.25 inches in length. These creatures are well suited to a residence in these ponds. Some of them, at least, can breathe either in water or in air, and hence can travel to other pools if the water dries up. A part of them never need to do this, for when the pools dry up, either in winter or summer, they resort to the mud and rubbish of the exposed botton, close up their shells, and remain inactive till the water comes again. They are ordinarily seen creeping about over the bottom, where they feed upon inicroscopic plants and animals or upon decaying organic matter in the form of a slimy coat on sticks and mud. If pressed with hunger, they have been known to resort to animal food, and in some instances devour their own kind. Some of them burrow into the mud at the bottom and become torpid in winter, but more active species may be seen moving over the bottom under the ice. The eggs are laid in spring, attached in masses to sticks and dead leaves. The young hatch in two or three weeks, according to temperature. 


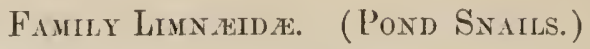

Physa ancillaria, Say.

(Say, Jour. Acad. Nat. Sci. Phil., v, 124, 1825.)

Common in Long Lake and in Willow Slough. The largest examples taken measure about .50 inch in length.

Physa heterostropha, Say.

(Limnea heterostropha, Say, Am. ed. Nich. Enc., pl. i, fig. $6,1817,1818,1819$ [as cited by Binney].)

This was probably the most commion snail in the bottomland pools. It is one of the thin-shelled species, with about four whorls, and differs from the preceding in having a longer and more tapering spire and a narrower aperture. Otherwise they are much alike. This is one of the most active and widely distributed of the species taken. It is said sometimes to attack and devour insects as large as itself. The eggs are deposited, according to Say, in the month of May, but probably at intervals during the summer also. Egg masses, which in all probability were from this suail, were quite frequently found attached to the outside of shells, where they had been left by other individuals. The shells were frequently clothed with growths of stalked infusorians.

Localities: Harkness Slough, Quincy Bay, Willow Slough, Cedar Creek, Wood Slough.

Helisoma trivolvis, Say.

(Planorlis trivolvis, Say, Am. ed. Nich. Enc., pl. ii, fig. 2, 1817, 1818, 1819.)

Common in many of the pools. Easily recognized by its depressed shell,- - the whorls lying nearly in one plane so that they can be followed on two sides of the shell. Large examples taken, measure five eighths of an inch in diameter.

Localities: Harkness Slough, Willow Slough, Lily* Lake, Long Lake, Wood Slough.

\section{Family Valvatide.}

Valvata tricarinata, Say.

(Cyclostoma tricarinata, Say, Jour. Acad. Nat. Sci. Phil., i, 13, 1818.) 
This small mollusk was common in many of the pools, but was not often brought out in the nets from pools in which it was very abundant. The shell is about.20 inch in diameter and may be recognized at once among our species by the strong ridges on the outside of the shell. It is somewhat depressed and the aperture is nearly circular in outline. The food is said to be vegetable matter. The eggs of related European species are deposited singly.

\section{Family Viviparida. (River Satalls.)}

Vivipara intertexta, Say. $244,1829$.

(Paludina intertexta, Say, New Harmony Disseminator, ii,

A common and uniformly distributed snail of rather large size. Shell rather stout, with about five strongly convex whorls. Adults dull reddish browu in color; young paler, with numerous fine revolving striæ on the whorls. The largest example taken measures one inch in length, with the largest whorl .87 inch in diameter. Inside the aperture may usually be seen several large reddish brown revolving bands. The young are born alive.

Localities: Harkness Slough, Willow Slough, Lily Lake, Long Lake, Wood Slough.

Vivipara subpurpurea, Say.

(Paludina subpurpurea, New Harmony Disseminator, ii, 245, 1829.)

Found only in Lily Lake. It is much like the preceding, but has a slightly more tapering shell with the whorls flattened next the revolving suture.

Campeloma decisum, Say.

(Limncea decisa, Say, Am. ed. Nich. Enc. 1, 1817.)

This was the largest and most abundant river snail observed. It may be distinguished from the two preceding by its more slender form, more tapering spire, and less convex whorls. The general color is a uniform olive green, more or less stained towards the apex with brown. Inside the aperture pure bluish white. An example measures 1.37 inches in length, with the largest whorl .87 inch in diameter. The young are brought 
forth alive, and may be found in the ovaries in the fall preceding the spring during which they are set free. The adults go into the mud at the bottom of the ponds and streams to hibernate.

Localities: Harkness Slough, Quincy Bay, Willow Slough, Lily Lake, Broad Lake, Wood Slough.

Lioplax subcarinata, Say.

(Limne'a subcarinata, Say, Am. ed. Nich. Enc. 1, 1816.)

Frequent in Willow Slongh. Similar to the preceding, but smaller and marked by an obtuse ridge extending along the middle of each whorl. One of the largest examples taken is just .50 inch in length. Like the other members of the family it is viviparous.

\section{Family Rissoide.}

Somatogyrus isogonus, Say. $22 \%, 1829$.

(Melania isogona, Say, New Harmony Disseminator, ii,

Numerous examples from Willow Slough, Aug. 15. Amnicola limosa, Say. 1817.)

( Paludina limosa, Say, Jour. Acad. Nat. Sci. Phil., i, 125,

Dredged in 3-5 feet of water, Willow Slough, Aug. 15.

The clams are not very different from the river suails in their way of living. They may be frequently seen in shallow water with the front part of the body buried in the mud and the soft, white "foot" thrust out of the shell. If watched intently under such circumstances they may be observed to move slowly forward, leaving a groove in the mud behind thens. In suitable places in quiet water they may become very abundant, forming what are known as clam beds. The food of some of our species consists entirely of microscopic plants and animals, such as algæ and protozoans. Some of the Unios are very probably scavengers, if we may decide from the condition of food in the stomachs of alcoholic specimens. In winter our species probably all go into the mud at the bottom of the streams and lakes, and there remain torpid until spring.

Their interest, viewed either from the standpoint of the fish-culturist or from that of the scientist, is very great. As 
Prof. Forbes has shown in his papers on the food of fishes, they constitute a large item of the food of some of our best fishes. The great abundance in which they occur in the water of this region must give them a decided influence, as competitors for food.

Of the two families appearing in the Quincy collection, the first is represented by small species which commonly pass for the young of the true clams (Unionidæ) of the second fanily. That they are adult animals is, however, easily shown with a magnifying glass, since by its means they may be seen in many cases to contain living young of relatively large size. The shells of these bivalves are not commonly more than half an inch in length.

\section{Family Corbiculide.}

Splurizum solidulum, Prime. 1851.)

(Cyclas solidula, Prime, Proc. Bost. Soc. Nat. Hist., iv, 158,

Common in shallow water in Willow Slough.

Spherium transversum, Say.

(Cyclas transversa, Say, New Harmony Disseminator, ii, $346,1829$.

Frequent in several of the pools.

Localities: Willow Slough, Long Lake, Broad Lake, Wood Slough.

\section{Family Unionide. (River Clams.)}

Anodonta grandis, Say.

(Say, New Harmony Disseminator, i, 341, 1840.)

This large, smooth, thin-shelled clam is common in most of the sloughs and lakes. It is probably the species which the channel catfish manages to tear from its shell. The shells recently emptied were sometimes brought out by seines in great numbers. Young and adults were seen in the sloughs and lakes, one of the furmer measuring .62 inch in length. A valve of a large one, picked up at the edge of Wood Slough, measured 6.\%5 inches in length.

Localities: Lily Lake, Broad Lake, Wood Slough. 
Anodonta imbecilis, Say.

(Say, New Harmony Disseminator, 1S29.)

Young examples about an inch long were very common in Wood and Willow Sloughs. The adults were not seen:

Localities: Willow Slongh, Lily Lake, Wood Slough. Unio alatus, Say.

(Say, Nich. Enc., Anı. ed., pl. iv, fig. 2, 1S16, 1818, 1819.)

Taken in Willow Slough and Lily Lake.

Unio gracilis, Barnes.

(Barnes, Silliman's Jour., ii, 174, 1823.)

Taken in Willow Slough.

Unio lavissimus, Lea.

(Lea, Am. Phil. Soc., iii, pl. 13, fig. 23; Obs. on Genus Unio, I.)

This is one of the large compressed species with angular expansions of the dorsal or hinge portion of the shell. The young are especially noticeable because of the large relative size of these angular processes, and were very common in portions of Wood and Willow Sloughs. In Lily Lake, also, they were numerous, but were not seen elsewhere.

Unio parvus, Barnes.

(Barnes, Silliman's Jour., vi, 174, 1823.)

Examples of this small clam 1.62 inches long were taken in Harkness Slough. It was not observed outside the levee.

\section{INSECTA.}

Unfortunately, little has been done on aquatic insects by entomologists, beyond describing and naming the species, and a search through the writings of American and foreign authors does not yield much of the particular kind of knowledge of which practical fish work stands in need. The food habits and transformations especially have been greatly neglected. We cannot therefore give such an account of the species collected as could be wished, but shall aim to add something to a knowledge of food habits in certain cases, and to point out, as clearly as we can in a brief paper, the forms whose acquaintance the economic ichthyologist needs to make. 
An exhaustive treatment of the group in its relations to fish culture would call for an account of every order of the class; for while such orders as Hymenoptera and Lepidoptera are very largely terrestrial, a glance at Prof. Forbes's most recent paper on the food of fishes will show that even bees, moths, and lepidopterous larvæ are devoured when chance brings them within reach. Freshets surprise and carry into the current of streams great numbers of terrestrial beetles and bugs which live in the earth, under dead leaves and on vegetation, and these furnish at such times no inconsiderable part of the food of the smaller fishes.

The common aquatic insects belong to the following orders: Diptera, Coleoptera, Trichoptera, Neuroptera, Hemiptera (true bugs), Ephemeridx, Plecoptera, and Odonata. Some of these live in the water throughout life; others in the larval and pupal stages; still others in the larval and mature stages; while a part are aquatic only in the larval condition. The food varies greatly with the species and may vary with different stages of the same insect. It consists of decaying organic matter, or of living plants or animals, while some forms constantly take a mixed aliment. It is not possible therefore with our present knowledge of the subject to calculate the effect of a sudden removal of the whole group from its relations to the other life of our waters; but considered only as fish food there can be no doubt that the effect would be decidedly to the detriment of fishes. Even those insects that prey upon the eggs and young of fishes are themselves in turn devoured by the adult fishes, and there seem to be very few indeed of the aquatic insects that are not eaten by fishes in greater or smaller numbers.

\section{Order Diptera. (Flies.)}

Flies of at least nine families are aquatic in the larval stage; but the majority of the individuals commonly collected in our waters pertain to the families, Simulidx, Culicidæ, Chironomidx, and Tabanidx. To the first-named family belong the notorious black fly and buffalo gnat. The larva of a very similar species (perhaps the same as one or the other) is very common in winter and early spring under rocks and wood in 
spring-fed streams in Illinois, but the flies are not known to damage stock in this region (central Illinois). The larva of this family are eaten by trout, and occur in the stomachs of other smaller fishes. The pupa live in leathery cases attached to the underside of stones and other objects in the water. The adult fly emerges under water in the spring of the year. Cedar Creek is exactly suited to these insects, and we should expect to find them there at the proper season.

The families Culicide and Chironomida contain the mosquitoes and gnats. The larva occur in water at all times of the year, so that in all probability a succession of broods are reared each season. Some species, at least, are found in water when cold weather comes in the fall, and doubtless remain in the larval condition till the next season. The eggs are placed in small masses on the surface of the water, where they float till the larva emerge. The food is believed, commonly, to be decaying organic matter, so that the larvæ have been thought to offset in a measure, as fish-food and as scavengers, the inflictions of the adults. They are extremely common, and may be captured at night in surface nets literally by the pint.

The family Tabanida (the horse flies) contains a number of species with aquatic larva. The eggs, which are elongated, smooth and shining. and of a dark culor, are deposited in masses by the flies on rushes and other aquatic plants in the latter part of summer. The larve live during the winter in the water, lurking about under submerged wood or refuse. They are carnivorous, and with their strong mouth parts can inflict a severe bite. From their strength and activity they must destroy great numbers of the smaller aquatic auimals. One kept by the late B. D. Walsh, fed upon a number of mollusks, pushing its way into the shells as far as it could, as it devoured the owners. Notwithstanding their aggressive ways, quantities of them are sometimes taken by the channel catfish (Ictalurus punctatus), and they are eaten, at least occasionally, by bull pout.

\section{Family Culicidx. (Gnats and Mosquitoes.)} Culex sp.

The adults of one or more mosquitoes were moderately comnion about the sloughs. The larvie were not observed 
except in one of the more stagnant bodies of water, but were probably present in all. These insects pass the winter in the winged state, hid away in cramnies. The larve swim head downward, and are the "wigglers" of neglected cisterns and rain barrels. The food during aquatic life is probably decaying organic matter.

Corethra sp.

The larva of this genus are small, worm-like creatures, those from Quincy about .32 inch long and .028 inch in diameter. The body is cylindrical, tapering towards the posterior extremity. 'I'he head is provided with a perplexing variety of structures for the perception and management of food, including eyes, antennæ, biting jaws, and a number of other tactile and prehensile appendages. In front of the eyes the head resembles a truncated cone, and at the blunt front extremity is attached a pair of antennæ consisting each of a long basal segment, from the free extremity of which arise from three to five long, curved, and tapering rods. Near the posterior end of the body is a series of long, plumose filaments. The body is beautifully transparent in life, and within it may be seen, near each extremity, a pair of pigmented, kidney-shaped respiratory saes.

The pupæ may be distinguished from those of the next genus by the presence on each side of the thorax of an odd, bladder-like respiratory structure, the two resembling a pair of ears. At the posterior end of the body is a pair of large fanshaped fins, by means of which the pupæ swim freely in the water. The adults are small, weak, obscurely-colored gnats, which are not often observed. Two species of Corethra are recorded from this country.

Our larva resemble those of the European Corethra plumicornis, but differ apparently in some details of form, - as in the shape of the eyes, and of certain leaf-like tactile appendages in front of the mouth.

The eggs are laid enclosed in a gelatinous material, arranged spirally in a single series in disk-sinaped masses, and float at the surface of the water till the young larva emerge. This occurs about a week after the eggs are laid, but probably the time varies greatly with the temperature. 


\section{Family Chronomid.e. (Gnats.)}

The familiar aquatic larva of this family belong to the genus Chironomus. Probably no other one genus of insects constitutes as important an item in the food of as large a number of fishes. They may be recognized by their uniformly cylindrical bodies, small heads, enclosed in an opaque crust, aud with a bilobed foot-like process bearing a dense brush of curved bristly hairs extending forward beneath it. At the posterior end of the body is a pair of false feet, also characteristic, each bearing a circlet of retractile hooks. The head is smaller relatively than that of the larva of Corethra, but under the microscope the parts appear almost as complicated. The structures present, however, are mainly in the nature of biting organs, the parts having to do with perception being here poorly developed. Thus the jaws are well developed, the edges of the mouth-opening are furnished with numerous teeth and hooks, and the labium is a broad plate with strongly toothed edge, while, on the other hand, the eyes and antennæ are very small. All this corresponds with what is known of the food of the larvæ. Their digestive tube is often filled with a browu granular material, consisting, as nearly as can be made out with the microscope, of decomposed organic matter containing great numbers of bacteria and a good many empty frustules of diatoms. In one example was found the fragments of an insect. The organs for mastication, complicated as they are, would hardly be equal to the complete obliteration of the cellstructure of plants and animals, were these the aliment upon which the larvæ depended, and I believe that the material in the alimentary canals examined was dead when taken. The diatoms were not more frequent than they would be if taken in the slimy coating which collects on submerged objects. . The insect fragments, which were of rather large size, bore evidence of having formed a rejected skin; while the abundance of bacteria among the alimentary contents points also in the same direction.

The larve are often of a blood-red color. They swim by a wriggling movement when in open water, but commonly live at the bottom, under stones and rubbish, where they construct 
galleries of agglutinated sand in which numbers live together. They may be found in water at all seasons of the year, even under the ice in winter. Quite a number of species are represented by the larvæ taken at Quincy, and some of the forms described below may represent several related species instead of one.

The pupæ differ from those of Corethra in having cottony tufts or antler-shaped fleshy respiratory appendages on each side of the thorax; but some apparently lack these structures. Those with the cottony tufts were common in the galleries under rocks. The ones with antler-shaped respiratory structures were taken at the surface in the bay, and may prove to be free-swimming. Several of these latter had the posterior part of the body enclosed in the larval skin.

The winged adnlts were emerging at the surface of the bay August 8 . Those captured, nearly all females, were brought in by the surface net, and are probably among the smallest of the genus, being only about .08 inch long. Color, pale yellow, with three large, brown, longitudinal spots on the thorax, the middle one placed before the others and continued behind by a very narrow median brown line. Segments of abdomen brown centrally above; pale at the margins and below. Antennæ, legs, and balancers, whitish. Wings unmarked. One male taken is more distinctly marked, and shows some dusky on the legs and ventral side of the thorax, while the plumose antennæ are decidedly blackish.

\section{Chironomus, larta (1).}

Large examples of this larva average about.44 inch in length. Head, yellowish brown. Eye-specks, two. Labium with strongly arched anterior edge, cut into about six black teeth on each side, with a median tricuspid tooth. Posterior segments with three pairs of fleshy (respiratory?) appendages; the first pair short and club-shaped, attached at the posterior edge of the antepenultimate segment, the second and third pairs long and contorted, attached the one to the middle and the other to the posterior edge of the penultimate segment. The four anal papillie rather slender, enlarging a trifle distally. 
Pupa constantly found in sand galleries with this larva have a pair of strong frontal hooks and are provided with cottony respiratory tufts on the thorax. Length about .32 inch.

These larve and pupæ were taken in numbers under rocks, a short distance within the mouth of Cedar Creek. Young short-nosed gars (I. plutystomus) had invaded the creek from the bay and were busily probing the crannies and feeding on the insects. One hundred and eighty-three larva and forty-two pupa were counted in the stomach of a single gar about nine inches long.

Chironomus, larva (2).

About equal to (1) in size. Head pale brown, under side black. Two eye-specks. Jabium with four teeth on each side; median tooth shorter than the two next it. Hairs of anterior pediform appendage rusty. A single pair of small club-shaped (respiratory?) appendages at posterior edge of the penultimate segment. Anal papillæ conspicuously enlarged distally. Less common than (1), but more widely distributed.

Localities: Willow Slough, Cedar Creek, Broad Lake, Wood Slough.

Chironomus, larea (3).

Small; the largest of two examples taken; only .24 inch long. A single eye-speck. Posterior segments without fleshy respiratory appendages. Anal papillæ apparently jointed.

One example each from Willow Slougl and Cedar Creek. Chironomus, larea (4).

A single very large larva, 1.38 inches long, from Ballard Slough, seems to differ from all the preceding. Head black beneath; eye-specks two. Labium with a large truncate median tooth, with a small tooth each side of it; outside the latter, two other large truncate teeth,- - about four teeth, large and small, on each side. Posterior segments without fleshy respiratory appendages. Anal papillæ not jointed.

\section{Chironomus, larva (5).}

A very small pupa (.12 inch long) taken August 7 within the mouth of Cedar Creek still retained its larva skin, the 
labium of which differs from that of all the preceding larva in. lacking the median tooth. Its condition would not permit of more extended comparison with the others, and it may prove the same as (3).

Ceratopogon, larea.

This is an extremely slender, transparent larva, resembling a vinegar eel, with eight long hairs radiating from the posterior body segment. It has been noted by Professor Forbes in the stomachs of fishes.

Common among algæ in Lily Lake August 15.

\section{ORDER COLEOPTERA. (BeEtles.)}

The aquatic members of this order of insects frequently have some or all of their limbs flattened and fringed to fit them for rapid locomotion in the water. Others show little in their structure that is adaptive to aquatic life, and simply creep about under water or cling to submerged vegetation much as a terrestrial beetle might. They are all, when adult, obliged to come to the surface for air, which they take and hold in bubbles by means of antennæ, wing-covers, or legs. Some of the larva also come to the surface for air, but others are provided with special respiratory structures by means of which they are enabled to get oxygen from water. Only the larvæ and adult beetles are aquatic. The larva quits the water when ready to become a pupa, and commonly burrows into the neighboring banks, where it excavates a small chamber in which it pupates. The adult on emerging returns at once to the water.

Many beetles in both larval and adult stages are very destructive to small aquatic animals of other kinds, and even attack fishes of considerable size. Tadpoles many times larger than these insects are often devoured. Some eat only the dead of other insects, while still others feed largely on vegetation.

The families containing aquatic species are Amphizoidac, Haliplidae, Dytiscida, Gyrinida, Hydrophilida, Parnida and Dascyllida. The great majority of individuals and species 
commonly taken in water pertain to the Haliplida, Dytiscidæ, Gyrinidx, and Hydrophilidx. Several other families may appropriately be considered in connection with aquatic insects because of their constant abundance in the moist earth along water and on sub-aquatic vegetation. These beetles are unquestionably an important source of food to the carnivorous aquatic animals, and themselves doubtless attack and devour their aquatic neighbors when chance brings these latter ashore.

\section{Family Carabida. (Predaceous Ground Beetles.)}

A few species of Bembidinm and Elaphrus were generally to be found on sunny days at the edges of sloughs, running over the mud. Under the logs in the neighborhood were the usual carabids of such situations - Galerita, Chlænius, and Pterostichus - but they were by no means common. The seining operations sometimes revealed the presence of certain burrowing species, such as Omophron americanum, in the moist mud of the shores; and in the latter part of August a sudden rise in the water surprised numerous examples of Clivina and Bembidium, which were noted floating on the surface at the mercy of predaceous aquatic animals.

\section{Family Haliplid}

The larvæ of this family are odd-looking creatures with strong spines or long-jointed respiratory appendages on the segments, the 9th (last) segment being produced and divided. Tarsi with a single claw. The larvæ of our two genera may be recognized by the following characters :

Haliplus.-Spiracles present, no branchial filaments. Maxillary palpi three-jointed. Clypeus truncate.

Cnemidotus.-No spiracles, branchial filaments long and jointed. Maxillary palpi two-jointed. Clypeus notched. .

Cnemidotus 12-punctatus, Say.

(Haliplus 12-punctatus, Say, Trans. Am. Philos. Soc., N. Ser., ii, 106, 1825.)

The beetles were moderately common in Willow Slough, where they were brought out by the dredge and dip net. Females taken August 15 contained ova with advanced embryos. 


\section{Family Dytiscide. (Predaceous Water Beetues.)}

The larvæ of these beetles are known as water-tigers from their rapacious habits. They have smooth bodies and long sickle-shaped jaws. In addition to these characters may be mentioned, as distinguishing these larvæ, the laterally placed antennæ, the presence of two claws on the tarsus, and the apparent absence of the 9th segment of the abdomen.

Both adults and young lead a predatory life, attacking and devouring whatever they can master. They do not hesitate to attack animals many times larger than themselves and are very destructive in fish ponds to young fishes. They are in turn eaten by the larger fishes. They live, in some cases, several years. In the fall some of the beetles go into the mud to hibernate; others may be seen actively swimming about in midwinter; and a few leave the water to hibernate under rubbish. The eggs are laid at intervals, and are scattered. Some, at least, of the larvæ become pupæ in the fall and emerge as adu lt beetles the following spring.

Laccophilus maculosus, Germ.

(Germar, Ins. Spec. Nov., p. 30 [as cited by G. R. Crotch]; Say, Compl. Writ., ii, 514.)

From Cedar Creek, Aug. 8. Apparently not common.

Laccophilus fasciatus, Aubé.

(Aubé, Species Ciénéral des Coléoptères, vi, 423, 1838 ; Crotch, Trans. Am. Ent. Soc. iv, 400, 1872-73.)

This small beetle, generally common in our ponds and lakes, was seeu only in Cedar Creek.

Bidessus lacustris, Say.

(Hydroporus lacustris, Say, Trans. Am. Philos. Soc., N. Ser., ii, 103, 1825; Compl. Writ., ii, 517.)

A minute species taken in Willow Slough and Cedar Creek. Hydroporus aulicus, Aubé.

(Auhé, Species Général des Coléoptères, vi, 572, 1838 ; Crotch, Trans. Am. Ent. Soc., iv, 396, 1872-73.)

Not rare in Wood Slough. 
Hydroporus vittatipenuis, G. \& $\mathrm{H}$.

(II. lineatus, LeConte, Proc. Acad. Nat. Sci. Phil., vii, 296, 1SS5.)

Common in Willow Slough.

Hydroporus consimilis, Lec.

(LeConte, Agassiz's "Lake Superior," 214, 1850.)

Very abundant in crannies of decaying and submerged wood in Willow Slough.

Hydroporus hybridus, Aubé.

(Aubé, Species Général des Hydrocanthares et Gyriniens, $573,1838$.

Common in Long Lake Aug. 9. Also found in Broad Lake and Willow Slough.

Coptotomus interrogatus, Fabr.

(Dytiscus interrogatus, Fabr., Systema Elentheratorum, i, 267, 1801; Croteh, Trans. Am. Ent. Soc., iv, 413, 1872-73.)

Very abundant in Willow Slough and common in Long Lake and Cedar Creek.

Acilius, larva.

This larva is a trifle more than an inch long (1.12 inches), with a fusiform body terminating behind in a pair of short naked caudal stylets. It agrees very closely with the account of a European species (Acilius sulcatus) given by Schiödte. The head is rather small, with two contiguous brownish black spots on the front, and a median spot of this color midway between these and the posterior margin. Sides of head dusky. Segments of thorax and abdomen pale olive above, the scutes of the abdominal segments narrowly edged with black, under parts and legs chiefly white. It differs from the European species in the form of the ligula, which is produced, and furnished at its tip with two strong setæ.

From Cedar Creek, Aug. S.

Thermonectes basilaris, Harr.

(Harris, N. E. Farmer [as cited by Crotch]; Crotch, Trans. Am. Ent. Soc., iv, 402, 1872-73.) 
About .44 inch long, general color black, with front, sides of thorax, and elytra yellowish brown. A line of this color also across the middle of the thorax. This was the largest beetle of its family taken at Quincy. It was captured in the same locality as the larva preceding, and may prove to be the adult, since the genera Acilius and Thermonectes are closely allied.

Locality, Cedar Creek.

\section{Fanily Gyrinide. (Whirligic Beetres.)}

These are the shining black beetles so often seen in large numbers circling about on the surface of the water. The three American genera all have representatives in Illinois. They secrete a milky fluid which probably is offensive to fishes, since notwithstanding the great numbers in which they occur, they are very rarely eaten by other animals. The eggs are placed in parallel rows on the leaves of plants in the water. The larvæe of European species are fully grown at the baginning of August, aud creep up rushes and spin upon these a papery cocoon. The adult beetle emerges from this in about a month and returns to the water, where it hibernates in the mud. In some cases the cocoon is placed at some distance from the water, under the bark of trees. The beetles are said to feed on dead insects. The larvæ may be known by their long slender bodies, the nine abdominal segments of which are furnished at each side with long fringed respiratory appendages. Tarsi with two claws. Posterior end of body with four curved hooks. Gyrinus analis, Say.

(Say, Trans. Am. Philos. Soc., ii, 108, 1825 ; Compl. Writ., ii, $520,562$.

A suall Gyrinus, which I presume to be this species, was seen frequently on the pools in immense swarms, often with a few specimens of the larger Dineutes among them. When they were dipped up and carried ashore they turned and hegan making their way back to the water with surprising unanimity. This evident knowledge of their whereabouts and ability to take care of themselves on land was quite in contrast with 
the behavior, under similar circunstances, of the equally common water bugs of the genus Corisa. The latter, when bronght ashore by the nets, scattered in every direction, and few of them ultimately reached the water again. The food of those examined consisted entirely of tragments of insects, which, judging by the large number of hairs, scales, and fragments of legs, were from moths which had fallen upon the water. Other species of Gyrinus from other parts of the State have been found to contain similar matter, from which it seems probable that they depend upon food of this character.

Dineutes assimilis, Aubé.

(Cyclinus assimilis, Kirby, Fauna Bor. Am., iv, 78, 1837 ; Dineutes assimilis, Lec., Proc. Acad. Nat. Sci. Phil., xx, 366, 1865.)

Two of three specimens examined contained fragments and scales of moths; and the third had eaten fragments of small predaceous land beetles and an aquatic worm,-Lumbriculus, or of some allied genus. The beetles are the common large whirligig beetles of ponds and lakes everywhere in the State. They were common in most of the pools at Quincy, and a few were noted sheltered among the branches of a partly submerged tree that had fallen into the swift current of the Mississippi River.

Gyrime, larva.

A small larva about .25 inch long, from Wood Slough, agrees exactly with published accounts of larvæ of this genus. Only one example was taken, though donbtless they were common, judging by the abundance of adult beetles.

FAMILY HydRopHILIDA.

In the beetle state the food of this family is largely decomposing vegetable matter. Occasionally the large species attack mollusks or amphibians. The larva are carnivorous, and, like those of the Dytiscida, do a good deal of damage in fish ponds. They have a single tarsal claw. The labrum is wanting. The Sth pair of spiracles is terminal, and the posterior end of the body is devoid of hooks. Some have fringed appendages along the abdomen like those of Gyrinus larva. 
The eggs are placed by the female in a silken case, sometimes attached to leaves or sticks which keep it at the surface, in other cases carried about by the beetle. A single case may enclose a hundred or more eggs. After hatching, the young larve remain for some time in the case, where they are protected from their enemies and insured a supply of air by being kept at the surface. A European species, very similar to our large black Hydrophilus, becomes fully grown as a larva in one hundred days, and leaves the water to burrow in the earth for pupation. The beetles hibernate in the inud and under rubbish.

Hydrochus squamiger; Lec.

(LeConte, Proc. Acad. Nat. Sci. Phil., vii, 35̃9, 1855.)

Found in Willow Slough August 15. Not common.

Hydrophilus nimbatus, Say.

(Say, Jour. Acad. Nat. Sci. Phil., 203, 1823; Compl. Writ., ii, 130.)

This species is evidently a scavenger. The digestive tube is long and coiled like that of a tadpole. It is commonly filled with a brown matter, largely granular and unrecognizable, among which are numerous diatoms, desmids, and fragments of filamentous algæ.

Moderately common in Willow Slough and Cedar Creek.

Berosus pantherinus, Lec.

(LeConte, Proc. Acad. Nat. Sci. Phil., vii, 36t, 1855; Horn, Proc. Am. Philos. Soc., 1873, 122.)

A common and widely distributed species. The long intestine is filled with matter like that found in Hydrophilus nimbutus,-probably largely decaying vegetable matter. Mixed with the granular matter are many diatoms and bits of filamentous algx.

Localities: Harkness Slough, Willow Slough, Cedar Creek, Long Lake, Wood Slough.

Berosus striatus, Say.

(Hydrophilus striatus, Say, Jour. Acad. Nat. Sci. Phil., N. Ser., v, 188, 1825; Compl. Writ., ii, 292.) 
Food like that of the preceding species, the only recognizable objects in the alimentary canals being in this case diatoms.

The species is abundant in Cedar Creek, and was found also in Ballard Slough.

Hydrophilide, larva (1).

A small larva with depressed and rather stout body, with a median brown band on the head and a pair of obscure dusky longitudinal stripes on the abdomen above. Pale below. Sides of thorax and abdomen tuberculate. The mandibles are unlike any others we have seen. They are rather long, sickle-shaped, and bear at about the middle of their inner edge a strong tooth with bicuspid apex, minute denticles on its anterior edge, and one or two small teeth at its base. The largest example taken is a trifle more than a half inch long.

Locality, Cedar Creek.

Hydrophilide, larva (2).

A small larva about.25 inch long, common in Cedar Creek, is evidently the young of one of the above species of Berosus. The body is widest at the middle and tapers pretty uniformly to the extremities. Head small; ocelli superior; clypens denticulate. Basal segment of maxilla unusually long and strong. Segments of body coarsely wrinkled, the seven auterior divisions of the abdomen, each with a pair of long, naked respiratory filaments. Terminal segment nipple-shaped; no caudal appendages. Young examples are transparent in life, but grow more opaque when older.

Family Staphylinide. (Rove Beetles.)

Small species of this family of beetles were always common in the mud and sand at the edges of sloughs, and many were noticed floating and struggling on the surface in the latter part of August, after the water had risen suddenly.

\section{Family Parnidex.}

These small beetles creep about or burrow in the mud under water. From the structure of the jaws they have been 
Animals of the Mississippi Bottoms near Quincy. $\quad 169$

supposed to be carnivorous. The larvæ are greatly flattened and live under rocks, sometimes in rapid currents.

Stenelmis vittipennis, Zimm.

(Trans. Am. Ent. Soc., ii, 259, 1S69; Horn, ibid, iii, 40, 1870-71.)

Taken in Willow and Wood Sloughs.

Macronychus glabratus, Say.

(Say, Jour. Acar. Nat. Sci. Phil., N. Ser., v, 187, 1827; Compl. Writ., ii, 292.)

Wood Slough, Aug. 4. Not common.

Family Heteroceridæ.

Heterocerus undatus, Mels.

This is a small brown pubescent beetle about .20 inch long, with a few irregular yellow marks on the wing covers.

It occurred in very great numbers in the earth at the edges of the more isolated sloughs, in burrows resembling miniature mole bills. When the seines brought the water over the burrows the beetles at once appeared and took flight. The larve also were present in abundance, and were found at times exposed on the surface of the water.

My attention was especially drawn to the curious little mud cases which the larvæ construct when ready to pupate, and of which $J$ have seen no published description. The cases are al ways made in the moist mud at the immediate edge of the water and are carefully detached from the adjacent soil, so that each stands in a little hollow. From one side arises a closed chimney often equal in height to the basal portion of the case. The beetles were emerging from the cases on the 11th of $\mathrm{Au}$ gust, al ways making their way out by creeping up the chimney and breaking through its extremity. The beetles were seen along most of the sloughs and lakes. The mud cases were noted as especially abundant along Long and Broad Lakes and Harkness Slough. At the edge of the first-named lake eighteen of the cases were counted on an area about one foot square. The food of both adults and larve consists of brown granular 
matter containing numerous diatoms, and of small cells, isolated and in chaplets, of what Prof. Burrill thinks is a Conferva,one of the alga which grow on moist surfaces.

\section{ORDER TRICHOPTERA. (CASE FliEs.)}

Larvæ of this group usually construct movable or fixed cases with openings at the ends. These cases are sometimes of peculiar shape, and oftener attract attention than the winged insects. They may be cylindrical, cone-shaped, spiral, like a flattened ink bottle, etc., and generally have bits of vegetation, or sand, fastened over the outer surface. The adults are small obscurely-colored insects, which usually take no food, and after depositing their eggs soon die. The eggs, enclosed in a gelatimous material, are placed on aquatic plants, the females, it is thought, sometimes descending into the water for this purpose. The larvæ feed on vegetable matter, such as dead leaves, stems, and wood, but sometimes devour also small insects and crustaceans. Those I have examined are abundant in small streams in central Illinois, and make large cylindrical cases, to the outside of which are fastened, longitudinally, numerous small sticks. The alimentary caual of this larva has always been found filled with decayed woody vegetable matter. The pune are formed in the cases, which are, if movable, fastened down by the larva previous to pupation.

Trichoptera, larva (1).

The common case-fly larva at Quincy was a somewhat unusual one as to habits. Most of our species creep slowly about on vegetation or on the bottom. This one is a free-swimming larva, and one or two were always taken when the surface net was drawn over the deepest water of Quincy Bay. It was captured on one occasion in the swift current of the river in a net drawn after the steamer "Hannibal Eagle." The case is trumpet-shaped, gradually decreasing in caliber from the larger end (which has a diameter of about .07 inch) to the smaller extremity, where the diameter is about .03 inch. The outside of the case has scattered bits of dead vegetable matter fastened over it, and numerous minute particles of sand. Fastened to 
one side, sometimes to $t$ wo sides, is a long rootlet or twig of a weed that may project at one or both extremities some distance beyond the case. The larva is plain white, with the head mottled with yellow and deep brown. Along the sides are attached fleshy respiratory filaments. The usual tubercles and hooks for adhering to the case are present. It swims by striking the water with the very long and heavily fringed hind legs, these being projected beyond the large opening for this purpose.

Trichoptera, larva (2).

A second larva lives in a short, conical case about .25 inch long, with a diameter of .125 inch at the larger and of .06 inch at the smaller end. The outer surface is thickly covered with bits of dead regetation, but lacks the long pieces which seem never to be absent from the other cases. The larva also is short and stout, but is not otherwise very different from (1). The posterior legs are not so long and slender relatively and the fringe is less perfect. This form was taken from the bottom in Willow Slough.

Trichoptera, pupa.

A pupa of some species of this group was taken in Willow Slough sealed up in its cylindrical case of dead vegetable materials. At the end towards which the head lay, a narrow slit had been left for the passage of water for respiration. Judging by the cast larval skin with this pupa, it cannot belong to either of the two larvæ described.

\section{ORDER NEUROPTERA. (HELLGRAMMITES AND LACE-WING Flies.)}

This order contains two families, the larva of which are very different in habit. The lace-wing flies are throughout life terrestrial, and are well known to gardeners and fruitgrowers for the good they do by devouring plant-lice. The hellgrammites or crawlers are aquatic during the larva stage and feed upon other water insects, such as case-fly and May-fly larve. They are themselves, to some extent, used by sportsmen as bait in catching fishes, their tough skin rendering them 
easily disposed and retained on the hook. They are furnished with seven or eight pairs of respiratory tilaments along the sides of the borly for use in the water, and have, besides, breathing pores (spiracles), which they use when they leave the water to pnpate in the earth. The tarsi have two claws. The eggs are deposited in large, whitish discoidal masses on the leaves of trees and on the sides. of boats and barges.

Corydalis cornutus, Linn. (Hellgrammite.)

(Walsh and Riley, Am. Ent., i, 61, 1868.)

The larvæ and adult of this large insect often attract the attention of those who live on our rivers. The species is not often seen in the interior of the State. Along the Mississippi River it is very common, though its abundance is not commonly apparent excepting during the ego-laying season. In August the wood barges and boats in the bay were resorted to by the females, and the masses of eggs were left in numbers upon the timbers.

\section{ORDER HEMIPTERA. (True Bugs.)}

This is one of the most important groups of aquatic insects, both on account of the food its members furnish to fishes, and also because of the serious injuries which some bugs do to fish eggs and fry. The genera Ranatra and Belostoma are especially to be remembered as containing some of che worst insect enemies to fishes of which we know. Most of them begin a predatory life as soon as hatched from the ego, and continue it without cessation throughout their existence. The common food consists of larve of other insects, mollusks, and the like. The eggs are generally deposited on aquatic plants, sometimes enclosed in gelatinocis matter, but in many cases quite naked. Corisa sometimes places its eggs on the shells of crayfishes. Eight families of the order have common representatives inthe waters of the State. Of these, five appear in the collection made at Quincy.

$$
\text { Family Hrdrobatid ж. (Crazy Bugs.) }
$$

Limnotrechus marginutus, Say.

(Gerris marginatus, Say, Heteropterous Hemiptera, 1831, 80\%.) 
The eggs of this "skipper" are attached to aquatic plants, and the young pupæ resenıble the grown insect except for the wings and increased size. In winter the adults are found under rubbish in the shallow water at the edges of streams. The species was common in a number of the sloughs, and was noted especially in Harkness Slough, Willow Slough, and Long Lake.

Stephania picta, H. Sch.

(Uhler, Stand. Nat. Hist., ii, 270.)

A small brightly colored insect taken only in Wood Slough and Long Lake.

\section{Family Velitide.}

Mesovelia bisignata, Uhler.

(Uhler, Stand. Nat. Hist., ii, 274.)

A small greenish yellow insect about .12 inch long, which is frequently found on the surface of water. Frequent at edges of Willow Slough August 15.

\section{Family Belostomatidx.}

Benacus griseus, Say.

This is one of the large, flat, predaceous bugs that sometimes become destructive to young fishes. It is reported by Mr. C. A. Hart, of this Laboratory, as common at the electric lights in Quincy. It was not seen in the water, but this was doubtless due to some peculiarity in its habits. For some reason it is never brought out in the seines and dredges in parts of the State in which the numbers taken at electric lights show it to be very common. Our small species of this family ( $Z$ aitha fluminea) often comes out in the seines by dozens.

\section{Family Nfapide. (Water Scorpiors.)}

Ranatra 4-dentata, Stål.

(Stå, Öfv. af kongl. Vetensk.-Akad. Förhandl., 1861, 204; Uhler, Stand. Nat. Hist., ii, 2כ̃.)

This bug is very slow of motion and creeps about on the bottom or on plants, depending on its resemblance to a piece of dearl vegetation for securing the animals upon which it preys, 
and for avoiding its enemies. It is said to puncture and destroy the eggs of fishes. Its own eggs are elongated and are provided with two long filaments at one end.

Family Notonectide. (Water Boatmex.)

Notonecta undulata, Say. 368.)

(Say, Heteropterous Hemiptera, 1831, 39 ; Compl. Writ., i,

An active, predaceous insect, capable of inflicting a severe sting with its beak when handled incautiously. The eggs, which are elongated, cylindrical, and white, are attached to aquatic plants. The young have been observed to emerge in May.

Taken in Quincy on Cedar Creek.

Plea striola, Fieber.

(Uhler, Stand. Nat. Hist., ii, 253.)

A minute, brown, hard-bodied species, which is quite common in many streams in Illinois.

Taken only in Willow Slough. Not common.

FAMILY CORISIDæ.

Corisa signata, Fieber.

(Fieber, Abhandl. Kön. Böhm. Gesell. Wiss., 1852, 233.)

This small species was extremely abundant in the temporary pools, especially so in Wood Slough.

Corisa alternata, Say.

(Say, Jour. Acad. Nat. Sci. Phil., N. Ser., iv, 329, 1825; Compl. Writ., ii, 251.)

This is the commonest Illinois Corisa. It was less abundant in some of the Quincy pools than the preceding, but was more widely distributed. Noted especially in Cedar Creek and Long Lake. The eggs are oval and have a small prominence at the free extremity. They are attached generally to plauts.

\section{ORDER ORTHOPTERA. (CRICKETS AND GRAsshoppers.)}

This is a strictly terrestrial group, and calls for mention here only because of the constant presence, on the banks of streams and pools, of species belonging to it, which doubtless 
have an effect as fish food, and otherwise on aquatic life. At Quincy, a small cricket (Tridactylus apicalis) occurred in myriads among weeds which were springing up from the mud at the edges of sloughs, and individuals were sometimes found upon the water.

\section{ORDER PLECOPTERA.}

Small insects, which, as nymphs, live under rocks and boards, often in swift-flowing water. The pupa takes food, and after attaining its growth leaves the water, and transforms to the winged adult. In a number of points they are allied to the grasshoppers.

Plecoptera, nymph.

A flat rymph found in Willow Slough. It is about .52 inch loug and bears at the end of the abdomen two long, jointed appendages. The antennæ are long and slender, the mouth parts much like those of a grasshopper or cockroach. Head very wide, and with a pair of compound and three simple eyes. Three divisions of the thorax large, with expanded terga, and bearing at each side cottony respiratory tufts. Legs with strong femora and three-jointed tarsi.

They were not common at Quincy, probably because the waters do not furnish them suitable shelter.

\section{order odonata. (Dragon Fues, Sxake Feeders.)}

These are predaceous when adult, feeding upon gnats, mosquitoes, flies, etc., which they capture while flitting rapidly about. Dragon fly larve and pupe have the reputation of preging upon other insects, and as a rule this will probably be found true; but an examination of several larva shows them to be in some cases largely vegetable feeders and possibly scavengers, the alimentary canal containing numbers of desmids, diatoms, fragments of moulds, and a good deal of macerial (probably slime) gathered from the bottom for the small organisms and the organic matter contained in it. The eggs are dropped into the water as the females fly over it, or may be attached to submerged plants. Nembers of one genus are said to go be- 
neath the surface and insert the eggs in the stems of plants. The young are common objects in the stomachs of fishes. The adults were not common about the pools in which the Fish Commission work was done. An occasional large species with clear wings was seen, and a small, slender-bodied form was noted as common about Lily, Long, and Broad Lakes. These were the only winged dragon flies seen. In the water, on the contrary, the immature stages of a number of species. were common. These latter fall into four groups, which, for the purposes of this paper may be chacterized as follows:

Antennæ filiform, of seven articles. Legs slender, not suited to digging. Abdomen long, cylindrical, terminating in three large, flat, leaf-shaped respiratory appendages. Includes numbers 2 and $3 \ldots \ldots \ldots \ldots \ldots \ldots \ldots \ldots$ Agrionina.

Antennæ stout, of four articles, the distal one rudimentary. Legs stout, suited to digging; tarsi of two anterior legs of two articles; tarsi of posterior legs of three articles. Labium not cleft. Includes numbers 4,5 , and $6 \ldots \ldots \ldots$ Gomphina.

Antennæ filiform, of six or seven articles. Legs slender; all the tarsi of three articles. Labium with a narrow median cleft. Labial palpi not expanded and spoon-shaped. Includes only numbers 7 and $8 \ldots \ldots \ldots \ldots \ldots \ldots \ldots \ldots \ldots \ldots$ Eschnina.

Antennæ filiform, of seven articles. Legs slender. Labium not cleft. Labial palpi expanded and spoon-shaped, meeting along the middle line. Includes number 9-12... Libellulina.

1. Agrion ramburii, Selys.

(Hagen, Syn. Neur. N. A., 1S61, 76.)

A small dragon fly with narrow transparent wings and slender body, with several of the hind divisions of the abdomen blne. Possibly the adult of one of the two following.

Common on the vegetation about Lily, Long, and Broad Lakes.

2. Agrionina, nymph.

A larva about .72 inch long; common in Long Lake. Chiefly brownish black. A pale, transverse band between the eyes, and a ring of minute, pale dashes at the hind margin of 
each abdominal segment. Legs chiefly white, a dusky band near the tip of each femur. Caudal respiratory appendages marked with broad, dusky cross bands; with a small spine at the apex of each, and with basal portion of edges spinose.

3. Agrionina, nymph.

A short larva, less than .25 inch long, with banded legs and antennæ, and a median dorsal pale line extending from head to end of abdomen. Possibly the young of the preceding, but I think not.

\section{From Wood Slough, Augnst 6.}

4. Gomplus, nymph.

The larger examples of these young from Quincy are 1.10 inches long. The aldomen is greatly depressed, but is quite uniformly, though slightly, convex above. Palpus of labium with inner edge toothed to the base, distal tooth not longer than the others. Front edge of labium without niedian tooth. The wing-pads do not quite reach the hind margin of the second abdominal segment. This agrees with Dr. Hagen's No. 12 in his "Monograph of the Early Stages of Odonata." Common.

Localities : Quincy Bay, Willow Slough, Lily Lake, Broad Lake, Long Lake.

5. Gomphus pallidus, Ramb., nynuph.

Dr. Hagen gives as the important characters of the young of this species, the presence of a median tooth on the front edge of the labinm, the presence of teeth along the whole inner edge of the labial palpus, a nedian dorsal spine on the hind edge of the 9 th abdominal segment, and the presence of lateral spines on abdoninal segments 7-9. It may be distinguished from the two species here noted by the presence along the middle of the abdomen, above, of an obtuse ridge. Very common in some of the sloughs, and of large size, several measuring 1.20 inches in length. All those taken in August were apparently about ready to yield the winged form. Young of this species were taken in Cedar Lake in October, 1882. From the two observations it seems probable that the adults emerge 
in the latter part of summer, and that the young hatching from their eggs hibernate in the mud.

From Harkness and Ballard Sloughs.

6. Gomphus notatus, Ramb., nymph.

These young are like the two preceding in general appearance, but lack the median tooth of the labium of number 4 and the dorsal ridge of number 5 . They differ from both of the preceding in having only about three blunt teeth on the inner edge of the labial palpi. The commonest Gomphus at Quincy. Of various sizes, some apparently ready to yield adults.

This is the Gomphus fluvialis of Mr. Walsh. Of the adult dragon fly, Mr. W. says that it flies constantly over water, and he thinks feeds exclusively on aquatic insects. It does not, as he supposed, breed exclusively in running water. Common.

Localities : Willow Slough, Lily Lake, Broad Lake, Wood Slough.

7. Anax junius, Drury.

The adult is one of our largest and commonest dragon flies. Its general color is obscure green, with some blue and black markings. Wings clear, with a yellow wash. The young are to be distinguished from all others taken at Quincy by the characters giren at the begiuning of this group. The very young are marked with wide transverse alternating bands of black and white.

Taken only in Long Lake, although the adults were seen now and then about several of the sloughs.

8. Epiceschna heros, (Fabr.) Hagen.

Two small nymphs, the largest one about .72 inch long, were taken in IVood Slough August 6. They were found clinging to dead sticks, depending apparently on their- dark, obscure colors for immunity from enemies. They agree in the main with Mr. Cabot's description of the young of this species. The antenna are of six articles, the distal one being longest. The labium is cleft, but lacks the tooth at each side. There are lateral spines on the abdominal segments $5-9$, and most of the segments have a median dorsal ridge terminating in a tooth behind. 


\section{Libellulina, nymph.}

A stout-bodied, pale brown nymph with scattered specks and spots of brown. Legs annulate with brown. Segments 8 and 9 of the abdomen with large lateral spines; no dorsal hooks or tubercles. The digestive tubes of several examples contained a good many microscopic plants and animals, together with a brown granular matter which I think had been gathered from the bottom. Extremely common in the upper part of Cedar Creek; the only young of this group taken there.

10. Libellulina, nymph.

With a general resemblance to number 9 , but rougher and the markings very obscure. A pair of tubercles between the eyes. A series of erect cultriform hooks on the middle of the abdomen, above. From the alimentary canal of one specimen a small mite was taken. Others examined did not contain food. Common and widely distributed.

Localities: Harkness Slough, Ballard Slough, Willow Slough, Lily Lake, Long Lake, Broad Lake.

11. Libellulina, nymph.

Much like 10, but with smoother body, and lacks the cephalic tubercles. A distinct dusky bar between the eyes. Legs annulate with dusky. Dorsal spines not cultriform, and not elevated behind. Not as common as the two preceding.

Localities: Lily Lake, Long Lake.

12. Libellulina, nymph.

Similar to number 10, and possibly the young of the same species. Tubercles of head relatively much larger. Dorsal spines tuberculiform, erect. Body more slender, nearly uniform blackish brown.

Two small examples from Willow Slough.

\section{ORDER EPHEMERIDE. (Mar Flies.)}

The adults of certain species of this group are familiar to any one who has visited our rivers in July. They blacken the willows at the water's edge and cause the limbs to droop, in 
such quantities do they collect upon them. In the evening, at times, they mount into the air, and may be seen in countless numbers moving for hours in one direction as if bent on migration. They are excellent food for fishes, as is attested by the avidity with which many of our fishes eat them, and were used as bait by sportsmen in the days of Isaac Walton. The winged insect takes no food, and lives only for procreation, but may, in confinement, live a week or more. The eggs are dropped into the water or are placed upon plants, the flies descending into the water for this purpose. The larvæ (nymphs) devour earth and sand containing dead and living animal and vegetable matter.

Hexagenia bilineata, Say.

This is the common brown May fly of Illinois rivers and lakes. It occurs throughout the length of the State, and often in such multitudes as to have acquired the name "mormon fly." It is commonly very abundant in the middle of July. In August, at Quincy, it was rare.

Hexagenia, nymph.

An elongated, whitish creature, "to be distinguished from most other aquatic insects by the presence of seven pairs of branchiæ, six of them plumose, attached along the sides of the abdomen and carried turned over the back. Jaws long and curved; front with an obtuse tubercle. Compound eyes, round, black; legs strong, suited to digging; abdomen terminating in three plumose stylets. Length of largest example taken at Quincy 1.20 inches. The food consists of earth richly charged with dead organic matter and with unicellular plants and animals. Such protozoans as Euglena are quite common in it. A large part of the contents of the digestive tube is sand, which seems to be taken incidentally. This is, in all probability, the young of $H$. bilineata.

It was common in Broad Lake; but elsewhere it was not often taken.

Localities: Willow Slough, Lily Lake, Long Lake, Broad Lake, Wood Slough. 
Canis, nymph (1).

A small brown form with three long, fringed caudal appendages, and with the respiratory appendages on segments 1-5 of the abdomen; those on segments $3-5$ concealed by the plate-like pair of the second abdominal segment. First respiratory appendages small, erect, not concealed. Head without conical tubercles. Autennæ, legs, and caudal appendages white, with brown annuli.

A few examples were taken in Willow and Wood Sloughs. Conis, nymph (2).

A second small nymph, from Willow Slough, has three prominent conical tubercles on the head which agree very closely with those of the European species C. luctuosa, as figured in Mr. Eaton's monograph of this group of insects. Our insect differs in having the prothorax narrowed towards the front; and in certain other characters does not quite agree with Mr. Eaton's description of the genus.

\section{ARACHNIDA. (Spiders and Mites.)}

Tetragnatha grallator, Hentz.

(Hentz, Bost. Jour. Nat. Hist., vi, 26, Pl. iv, figs. 1 and 2.)

A small, slender-bodied, long-legged spider, large examples of which are .50 inch in length. Extremely common about the sloughs and lakes, often living over the water, exposed on dead stems and branches. It was sometimes brought in by the small seines in situations such that it seemed it must have been in the water. Its food probably consists of small gnats.

Arrenurus sp.

A pale water mite with long ciliated legs was frequently taken by surface nets in the deep water of the bay. It is, I believe, a river species.

\section{VERMES. (WoRMS.)}

This group is not of the same importance to fish culture as are the crustaceans and insects-unless it be as parasitesand we shall not give those observed at Quincy more than a passing notice. 
One of the nost interesting of those noticed is a small cylindrical worm with a retractile caudal disc fron which arise four ciliated tentacles. It lives in great numbers in tubes on the under side of lily pads in Lily Lake, and when undisturbed lies with the hind end of the body out of the tube and, with the disc and tentacles expanded, sways slowly about. It will probably prove to be Dero intermedius, Cragin, though it is questionable if this is more than a variety of $D$. digitata, Mull.

Leeches which I have provisionally separated as five species were taken from the sloughs. All appear to belong to the genus Clepsine. Several of them were very common, being brought in on the shells of turtles, and at other times apparently attached to fishes.

Quite a variety of rotifers were observed, but none of special interest except the large and beautiful Conochilus volvox, colonies of which, consisting of a dozen or more individuals, were common in the open water of the bay, where they could always be taken in surface nets drawn after a skiff.

Plumatella arethusa, Hyatt.

(Hyatt, Observations on Polyzoa, 95.)

One of the branching polyzoans was very common in most of the pools, sometimes on sticks, on the under. side of stones, and, in Lily Lake, on the under side of the lily pads. The statoblasts were frequently noticed scattered among alga and rubbish.

Hyalinella vesicularis, Leidy.

(Plumatella vesicularis, Leidy, Proc. Acad. Nat. Sci. Phil., vii, 192.)

A single example of a small colony from Libby Lake, is referred to this species with some doubt.

Pectinatella magnifica, Leidy.

(Cristatella magnifica, Leidy, Proc. Acad. Nat. Sci. Phil., v, 265.)

The large masses of gelatinous matter so common in "back water" in this region, are formed by the colonies of this poly- 
zoan. The animals themselves are on the outside of the masses and constitute but a sniall part of the bulk of each mass. In the upper part of the bay, in the inlets and mouths of sloughs, this animal was very abundant. As the water subsided the masses were often exposed, and were left in numbers to decompose in the air. One of the largest masses seen measured 16.50 inches in greater dianeter by 12.50 inches in lesser diameter, with an average depth of about six inches. Small spindle-shaped colonies were common on the stems of dead weeds along the margins of the lakes. The shape of the colony seems to depend entirely on the character ofthe object upon which it is established. I could not see that fishes, or indeed anything else, fed upon the gelatinous material. Reproduction both by statoblasts and by eggs was in progress in August.

\section{CELENTERATA.}

Hydra fusca, Trembley.

These small animals are the closest allies of the corals and sea anemones of salt water, which our streams and lakes furnish. They are, when extended, about .25 inch long, and consist of a tubular body with a circle of tentacles about the one opening, the mouth. They are commonly found attached by the end opposite the mouth to plants and other submerged objects. I was surprised to find them on one occasion in Wood Slough in considerable numbers, and took others with the surface net in the bay, where they must have been floating at the surface. Those taken in Wood Slough, Aug. 4, were multiplying very rapidly by budding. The food consists of small animals which are captured by the tentacles.

\section{PROTOZOA.}

Notwithstanding their minuteness, the protozoa are of considerable importance as fish food, and are probably still more useful indirectly, since they constitute a large share of the food of insects.

At Quincy the animals of this group varied with the vegetation in the water. Where the plants were common, a variety 
of species and an abundance of individuals might be expected. In the river they were very rare. In the deeper water of the bay they were not as common as at its edges, among the wood rafts and the barges. They were most common in the stagnant water of the lakes. Such genera as Amœba, Difflugia, Centropyxis, Actinosphærium, Vorticella, and Euglena were abundantly represented. In Lily Lake a species of Pyxicola attracted attention from its abundance. It was noticed in the alimentary canal of the singular Dero mentioned above.

Two protozoans are especially deserving of mention here. The elongated green Euglena viridis was always to be found in water dipped up at any place in the bay. When the wind blew toward the west shore for a number of hours together a dense coherent green scum was observed to collect in the inlets and mouths of sloughs, and under the microscope this was found to consist largely of the contracted, spherical Euglenæ. When placed under the cover glass of the slide they soon become active again. Fishes and other animals could, and probably do, at such times collect them in quantities for food. The second protozoan is Arcella discoides, which occurred in numbers with the Euglenæ. 